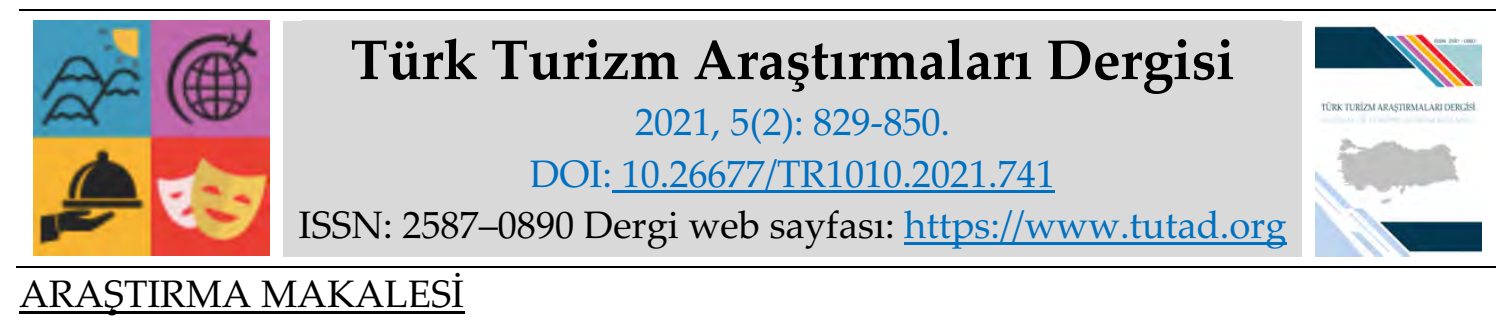

\title{
Termal Konaklama İşletmelerinde Sunulan Hizmetin, Müşteri Memnuniyeti Açısından Değerlendirilmesi: Kahramanmaraş Örneği
}

Ahmet CUMA, Uzman, Aile Çalışma ve Sosyal Hizmetler Bakanlığı, Kahramanmaraş İl Müdürlüğü, Kahramanmaraş, e-posta: ahmetcuma7@gmail.com

ORCID: https://orcid.org/0000-0002-2676-977X

Doç. Dr. Atınç OLCAY, Gaziantep Üniversitesi, Turizm ve Otelcilik Meslek Yüksek Okulu, Gaziantep, e-posta: olcay@gantep.edu.tr

ORCID: https://orcid.org/0000-0003-0407-5467

Dr. Öğr. Üyesi Ercan İNCE, Iğdır Üniversitesi, İktisadi ve İdari Bilimler Fakültesi, Iğdır, e-posta: ercan.ince@igdir.edu.tr

ORCID: https://orcid.org/0000-0003-4821-8140

Öz

Termal turizm, katılımcılarına tedavi hizmetleri sunmasının yanı sıra bölgesel kalkınmışlığı da arttıran önemli bir turizm faaliyetidir. Termal turizmi kullanan müşteriler hem tedavi olmak hem de doğanın etkilerinden faydalanmak suretiyle termal bakımdan hizmet veren işletmeleri tercih etmektedir. Kahramanmaraş îli termal kaynaklar bakımından diğer termal bölgeler ile rekabet edebilecek potansiyele sahiptir. Termal otel işletmelerini birbirinden ayırt eden faktör, müşterilerin termal otelde kaldıkları süre boyunca, aldıkları hizmetten memnuniyetin en üst seviyede tutulmasıyla mümkün olacaktır. $\mathrm{Bu}$ çalışmanın amacı, müşterilerin termal işletmelerden aldıkları memnuniyeti belirlemektir. Turizm işletme belgeli termal otellerin, Onikişubat ilçesi Döngele Kaplıcalarında faaliyet göstermesinden dolayı, bu bölgede konaklayan 483 müşteriye anket uygulanmış ve bu anketler SPSS 21 program aracilığı ile analiz edilmiştir. Analiz bulgularına göre, Kahramanmaraş ilinde ki termal tesislerde konaklayan müşterilerin işletmelerden aldıkları hizmetten memnun oldukları sonucuna ulaşılmıştır.

Anahtar Kelimeler: Termal Turizm, Müşteri Memnuniyeti, Döngele Otelleri.

Makale Gönderme Tarihi: 24.02.2021

Makale Kabul Tarihi: 03.06.2021

\section{Önerilen Atıf:}

Cuma, A., Olcay, A. ve İnce, E. (2021). Termal Konaklama İşletmelerinde Sunulan Hizmetin, Müşteri Memnuniyeti Açısından Değerlendirilmesi: Kahramanmaraş Örneği, Türk Turizm Araştırmaları Dergisi, 5(2): 829-850.

(C) 2021 Türk Turizm Araştırmaları Dergisi. 


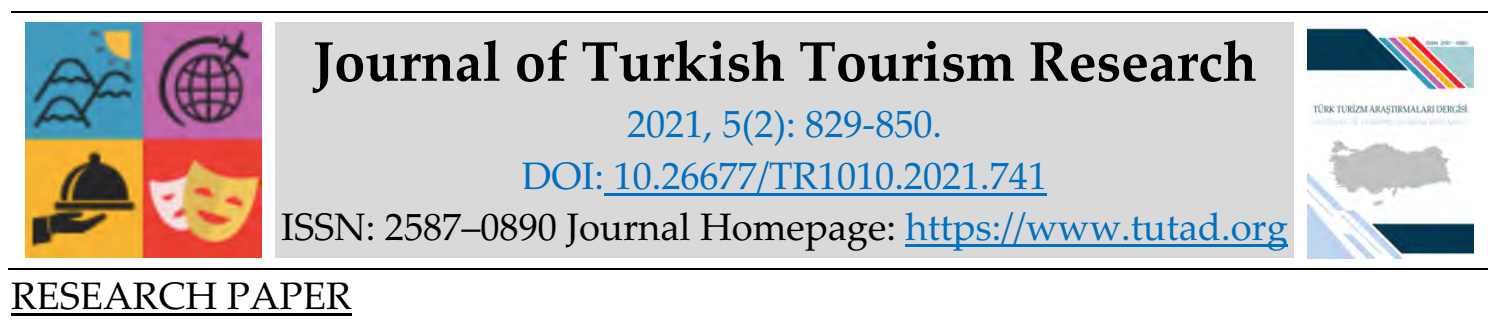

\title{
Evaluation of the Service Provided in Thermal Accommodation Businesses in terms of Customer Satisfaction: The Case of Kahramanmaraş
}

Ahmet CUMA, MSc., Ministry of Family Labor and Social Services, Kahramanmaraş Provincial Directorate, Kahramanmaraş, e-mail: ahmetcuma7@gmail.com ORCID: https://orcid.org/0000-0002-2676-977X

Associate Prof. Dr. Atınç OLCAY, Gaziantep University, School of Tourism and Hotel Management, Gaziantep, e-mail: olcay@gantep.edu.tr ORCID: https://orcid.org/0000-0003-0407-5467

Assistant Prof. Dr. Ercan İNCE, Iğdır University, Faculty of Economics and Administrative Sciences, Iğdır, e-mail: ercan.ince@igdir.edu.tr ORCID: https://orcid.org/0000-0003-4821-8140

\begin{abstract}
Thermal tourism is an important tourism activity that increases regional development as well as providing treatment services to its participants. Customers using thermal tourism prefer businesses that provide thermal services in order to being treated and to benefit from the effects of nature. Kahramanmaraş Province has the potential to compete with other thermal regions in terms of thermal resources. The factor that distinguishes thermal hotel businesses from each other will be possible by keeping the satisfaction of the customers at the highest level during the time that their stay in the thermal hotel. The purpose of this study is to determine the satisfaction of customers who stay in thermal enterprises. Since thermal hotels which has tourism management certificates operate in Dongele Hot Springs, Onikisubat district, 483 customers who stay in this region were surveyed and these surveys were analyzed through the SPSS 21 program. According to the analysis findings, it was concluded that the customers who stay in the thermal facilities in Kahramanmaraş were satisfied by the service they received from the enterprises.
\end{abstract}

Keywords: Thermal Tourism, Customer Satisfaction, Dongele Hotels.

Received: 24.02.2021

Accepted: 03.06.2021

\section{Suggested Citation:}

Cuma, A., Olcay, A. and İnce, E. (2021). Evaluation of the Service Provided in Thermal Accommodation Businesses in terms of Customer Satisfaction: The Case of Kahramanmaraş, Journal of Turkish Tourism Research, 5(2): 829-850.

(C) 2021 Türk Turizm Araştırmaları Dergisi. 


\section{Gíriş}

Termal turizm, insanlar arasında yeni dostlukların kurulması, destinasyonların kalkınması, bölgeler arası ilişkilerin geliştirilmesi ve insanlara sağlıklı yaşam hizmeti sunmasından dolayı birçok kazanımı bünyesinde barındırmaktadır (Karabacak, 2019: 8). 2023 Eylem Planında, termal turizmin geliştirilmesi, ülke kaynaklarının verimli bir şekilde hizmete açılması ve termal tesislerin artırılması, yatak kapasitesinin 500 bine çıkarılması gibi amaçlar belirlenmiştir (https://yigm.ktb.gov.tr). Termal turizme yapılan yatırımların artırılması, Dünya'da turizm alanında yüksek pay alınmasını sağlayacaktır. Turizmin, yalnızca güneş - kum - deniz üçlemesiyle kısır kalmaması, ülkemizde alternatif turizm türlerinin yapılmasına fırsat veren alanların olması, işletmecileri farklı düşüncelere ve arayışlara yönlendirmektedir (Amenguel vd., 2012: 2095; Arslan, 2018: 24). Bu amaçla termal turizm potansiyeli olan bölgeler, talebin on iki aya yayılması fikriyle, ülkedeki turizm faaliyetleri önemli bir ivme kazanacaktır (Sandıkçı, 2008: 107).

Termal kaynaklı suların, sağlık bakımından birçok faydasının olduğu bilinmektedir (Boyraz ve Çetin, 2019: 91). Halk tabiriyle "şifalı sular" olarak adlandırılan bu kaynaklardan içilebilir olanlara içme veya içmece, haricen kullanılabilenlere ise "kaynarca, hamam, ılıca, girme, 1lısu, çermik" gibi isimler verilmektedir. Turizm alan yazınındaysa, "termal merkez" ya da "kaplıca merkezi" olarak adlandırılmaktadır (Karademir vd., 2019: 642). Termal turizm işletmelerinde mal ve hizmetleri satın alan müşterilerin memnuniyetinin sağlanması, beklentiler ile doğru orantılıdır. Müşteri memnuniyeti, mal veya hizmetin kullanılmasından sonra ortaya çıkan etkidir (Cadotte vd., 1987: 305; Tam, 2011: 206). Bu sebeple, müşteri beklentilerinin bilinmesi, müşteri memnuniyetinin sağlanması açısından büyük önem arz etmektedir (Burucuoğlu, 2011: 16). Müşteriyi memnun etmek, müşterilerin beklentilerini karşılamak için günümüz termal otellerinin çok daha özverili çalı̧̧masını gerektirmektedir (Sandıkçı, 2008: 64). Termal turizm odaklı otellerde, müşterilerin ihtiyaç, beklenti ve isteklerinin belirlenmesi, bunların karşılanması nedeniyle oluşacak memnuniyet; otellerin kârlılık oranlarını yükselterek hem ülke ekonomisine katma değer sağlayacak hem de termal kaynaklı otellerde ulusal ve uluslararası turizmin sene boyunca canlı olmasına imkân sağlayacaktır (Olcay ve Giritlioğlu, 2014: 5).

Zhao (2017: 5)'nun araştırmasına göre, sağlık turizminde müşteri memnuniyeti, müşterilerin kaliteyi tecrübe ederek algıladıkları karşılıklı bir süreç olarak değerlendirilmektedir. Bu nedenle, bu tür işletmelerde müşterinin aldığı hizmetin memnuniyeti, hassas bir konudur. Örneğin, müşteri bir bilgisayar satın alır, bunun fiyatını öder ve bu üründen belli bir süre fayda bekler. Bunun gibi termal işletmeleri tercih eden yerli veya yabancı ziyaretçiler de satın aldıkları hizmetin karşılığında, sağllğa kavuşma, hastalığına şifa bulma ve zindeliğe kavuşma biçiminde otelden fayda beklemektedirler. Müşterileri anlayışla karşılamak ya da onları tanımak, dinlemek, onlara önemli olduklarını hissettirmek, varsa şikâyetlerini veya önerilerini göz ardı etmemek, müşterileri özel günlerde de daima hatırlanıldığını vurgulamak amacıyla internet veya mobil iletişim araçlarını kullanarak müşterileri onure etmek, müşterinin bir sonraki ziyaretinde aynı işletmeyi tercih etmesi halinde müşteriyi ödüllendirmek, memnuniyeti belirleyen unsurlar olarak önemlidir (Sav, 2016: 112). Bu araştırmanın yapılmasında, Kahramanmaraş'ta bulunan termal tesislerin bölgenin turizm faaliyetlerini etkilemesi ve müşteri memnuniyetinin termal turizme hangi ölçüde katkı yaptığının belirlenmesi önem arz etmektedir.

\section{KAVRAMSAL ÇERÇEVE}

Su, canlıların yaşam kaynağıdır (Uçar, 2017: 158). Gezegenin sahip olduğu su miktarının 1 milyar 400 milyon $\mathrm{km}^{3}$ olduğu bilinmekle birlikte \%97,5'ini okyanuslar (tuzlu sular), ana karada geriye kalan \%2,5'iniyse, içilebilir sular oluşturmaktadır (Kireçci vd., 2017: 20). Sularla ilgili bilimler, 
aslında Coğrafyanın alanına girmekle birlikte, bu konunun turizm ile ilgisini ise termalizm, kıyı turizmi, dalga sörfü, klimatizm gibi turizm çeşitlerinin, kaynağını sudan alması oluşturmaktadır (Kervankıran, 2013: 58). Anadolu'da, ilk çağlardan beri şifalı sulardan yararlanmada, sağlı̆̆ın ve dini düşüncelerin hâkim olduğu bilinmektedir (Usta ve Zaman, 2015: 188). Antik dönemde, termal suların şifa verici güçleri (Boekstein, 2014: 1), tanrıların sağllk verme kudretleriyle ilişkilendirilerek bu suların bulunduğu alanlara çeşitli tapınaklar yapılarak gizli güçlerden yardım beklenmiştir (Tsiftelidou ve Christodoulou, 2019: 253). Yıkanarak arınmak, bir ibadet olarak görülmese de neredeyse tüm dinlerde temizlik, dinin ilk koşulu olarak görülmektedir. Bu nedenle Antik çağlardaki kaplıcaları, ibadethanelerden ayırt etmek zordur (Sucu, 1990: 80).

Termal kaynaklar, doğal olarak yer altında belirli sıcaklıkta bulunan, insan eliyle ya da doğal olarak yer üstüne çıkan kaynaklardır. Termal kaynaklar bünyesinde sağlıklı minerallere sahip şifalı su, şifalı çamur ve buharların bulunduğu doğal şifa kaynaklarıdır (Balcığulları, 2013: 289). Termal su, yeryüzüne bazen sondajla bazen de doğal yollarla çıkmaktadır. Genellikle "1lıca" ya da "kaplıca" kelimeleriyle eş anlamda kullanılmaktadır (Göçmen, 2008: 43). Termal turizm ise, sağlıklı yaşam, sağlıklı tatil felsefesiyle insanların sürekli yaşadıkları bölgelerden ayrılarak, geçici olarak termal turizm hizmeti sunan tesislere gidip oradaki kaplıca (termalizm) ve iklim (klimatizm) özelliklerinin birlikte sunulduğu tesislerde, uzman fizyoterapist ve hekim eşliğinde, fizik tedavi ve kür hizmetlerini aldığı ve diğer turizm hizmetlerinden faydalanması sonucunda ortaya çlkan bir turizm çeşididir (Çelik, 2009: 19). Termal turizm kapsamında bedensel ve ruhsal rahatsızlıkları olan bireylerin, evlerinden ayrılarak değişik bölgelerde sağlık temelli tedavi görme istekleri, "termalizm” gibi turizm türünün ortaya çımasına sebep olmuştur. Termalizm kavramı, son yıllarda bir pazarlama stratejisi olarak kullanılmaktadır (Leandro vd., 2015: 5).

Tablo 1. Termal Kaynak Sular ve Tedavi Edici Özellikleri

\begin{tabular}{|l|l|}
\hline Termal Suyun Niteliği & Tedavi Ettiği Hastalıklar \\
\hline Sodyum klorürlü Kaynak & $\begin{array}{l}\text { Bronşit, sinirsel rahatsılıklar ve vücut yorgunlukları, kan } \\
\text { dolaşımı, romatizmal hastalıklar, astım, kalp ve deri hastalıkları }\end{array}$ \\
\hline $\begin{array}{l}\text { Hidrokarbonat } \\
\text { Karbonatlı Kaynaklar ve }\end{array}$ & $\begin{array}{l}\text { Romatizma, beslenme bozuklukları, idrar yolları ve böbrek } \\
\text { rahatsılıkları }\end{array}$ \\
\hline Sülfatlı Kaynaklar & $\begin{array}{l}\text { Romatizma, beslenme bozuklukları, idrar yolları ve böbrek } \\
\text { rahatsılıkları }\end{array}$ \\
\hline Demir içeren Kaynaklar & Kandaki demir oranının azlığı \\
\hline Arsenikli Kaynaklar & Bedensel Yorgunluklar \\
\hline İyot içeren Kaynaklar & $\begin{array}{l}\text { Kan dolaşımı problemleri, solunum yolları, kalp ve göz } \\
\text { hastalıkları }\end{array}$ \\
\hline Kükürt içeren Kaynaklar & Kadın hastalıkları, cilt, göz, romatizma ve solunum yolları \\
\hline Radon içeren Kaynaklar & $\begin{array}{l}\text { Hormonal bozukluklar, kalp, romatizma, kadın hastalıkları ve } \\
\text { kan dolaşımı problemleri }\end{array}$ \\
\hline
\end{tabular}

Kaynak: Bucak ve Özkaya, 2013: 9

Termalizm kavramının, sağlık turizmi kapsamında değerlendirilmesinin nedeni, sağlık turizminin çatısı altında yer alan termal su ve iklim değerlerinden belli kurallara bağlı kalınarak faydalanılan zindeleşme, dinlenme, sağlığa kavuşma arzusu içinde bulunan turistlerin amaçlarını gerçekleştirdiği turizm faaliyetidir (Silvestri vd., 2017: 56). Termal turizm faaliyetinden faydalanan insanlar, genellikle her yaştan katılan ve farklı öğrenim düzeylerine ve gelir grubuna sahip sağlığına kavuşma arzusunu taşıyan ya da sağlıklı olma durumunu devam ettirmek isteyen yerli veya yabancı turistlerdir. Çiçek ve Avderen (2013: 27)'e göre termal turizm 
veya kaplıca turizmi, genel olarak mineralize termal su banyosu, içme, inhalasyon, çamur banyosu gibi çeşitli türdeki yöntemlerin yanında; iklim kürü, fizik tedavi, iyileştirme, egzersiz, psikoterapi, diyet gibi destek tedavilerini de kapsayan turizm hareketi olarak tanımlanır (Erdoğan ve Aklanoğlu, 2008: 84; Boekstein, 2014: 3).

Kaplıca ya da ılıcaların oluşturduğu doğal su kaynaklarının tedavi maksadıyla, sağlık şartlarına uygun bir halde kullanılması sağlık açısından önem arz etmektedir (Şengül ve Bulut, 2019: 59). Termal kaynak sularının hangi tedavilerde etkili olduğu Tablo 1'de gösterilmiştir.

Termal kaynak sular bakımından Kahramanmaraş İli, önemli bir potansiyele sahiptir. Termal sular, bulundukları bölgenin jeolojik yapısına, ph değerlerine, tedavi açısından hangi hastalığa iyi geldiğine, sıcaklıklarına, eriyik minarel yapısına göre farklılık göstermektedir (Özşahin ve Kaymaz, 2013: 26). Kahramanmaraş'taki termal kaynakların bir kısmında sıcak, bir kısmında da soğuk diye nitelendirilen termal sular bulunmaktadır. Soğuk çıkışlı olanlar içme (maden suyu) diye tabir edilen sular gurubundandır. Sicak termal kaynaklar ise genellikle haricen kullanılan sulardandır. Bu ısı farklılığının temel nedeni ise atmosfer kaynaklı suların, yeryüzüne indikleri sırada topraktan süzülerek yeryüzü çatlaklarından sızıp fay hatları boyunca ısınarak veya ısıdan etkilenmeden yeryüzüne çıkışı esnasında minarelleri de içerisine alması ile oluşur (Gürbüz ve Korkmaz, 2004: 1544). Ülkemizde, 1500'den fazla termal kaynağın bulunduğu bilinmekle birlikte, diğer bölgeler kadar zengin olmasa da Kahramanmaraş, hipotermal ve hipertermal kaynaklarıyla önemli bir potansiyel oluşturmaktadır (Özbek ve Özbek, 2008: 103; Sandal ve Karademir, 2015: 43). Ağırlıklı olarak Onikişubat ilçe sınırları içerisinde bulunan Döngele Kaplıcası, Yel Değirmeni Ilıcası ve Süleymanlı Beldesinde bulunan Ilıca (Zeytun) kaplıcası potansiyel açısından önemli sıcak termal kaynaklarıdır (Uslu ve Kaya, 2015: 20; Karademir vd., 2019: 647). İçmeler içinde en büyük potansiyel ise Ekinözü ilçesinde bulunan Ekinözü içmeleridir. Ekinözü İçmeleri, aşağı, orta ve yukarı içme diye üçe ayrılmaktadır. Aralarındaki fark ise sıcaklık ve debileridir. Bunlardan başka Uyuzpınar, Dereboğazı, Hopur, Büyükkızılcık, Keklikoluk ve Çınarlı İçmeleri soğuk çıkışlı termal kaynaklardır. Her termal kaynaklı su, sağlık açısından farklı özellikler taşımaktadır.

\section{LITERATÜR TARAMASI}

Çontu (2006) tarafından yapılan araştırmada, alternatif turizm çeşitlerinin incelenmesi ve buna bağlı olarak Kızılcahamam'da faaliyet gösteren termal turizm işletmelerinde çalışanlar ile bu işletmeleri tercih eden müşterilere anket uygulaması yapılmıştır. Araştırmanın sonuçlarına göre, çalışanların "hijyen", "fiyat" ve "hizmet kalitesi" boyutlarında, müşterilerin ise "fiyat" boyutunda anlamlı farklılıklar gösterdiği belirlenmiştir.

Eleren ve Kılıç (2007) tarafından yapılan araştırmada, Afyonkarahisar'da faaliyet gösteren beş yıldızlı termal otel işletmelerinde kalite ölçme yöntemi olarak SERVQUAL ölçeğinden yararlanılmıştır. Termal otel işletmesinin hizmet kalitesinin, müşterilerin gözüyle değerlendirilmesi amacıyla 125 kişiye anket uygulanmıştır. Araştırmanın sonuçlarına göre, müşterilerin algılama düzeyleri yüksek çıkmasına karşın, beklentilerinin de yüksek çıkması, SERVQUAL skorlarını negatif büyüklüğe taşımıştır.

Keskin (2008) tarafından yapılan tez çalışmasında, Kızılcahamam termal turizm işletmelerini tercih eden 322 kişiye anket uygulanmıştır. Anketten elde edilen sonuçlara göre, Kızılcahamam' daki termal turizm işletmelerinde konaklayan müşterilerin büyük çoğunluğunun; Kızılcahamam'daki termal turizm işletmelerinden memnun kaldıklarını, işletmeleri yeniden tercih edeceklerini, işletmeyi başkalarına tavsiye edeceklerini ve aynı tatmini başka işletmelerden alsalar bile yine bu işletmeleri tercih edeceklerini belirtmişlerdir. Sonuçlarda dikkat çekici diğer 
bir ayrıntı ise, değişkenler ile müşteri tatminini etkileyen faktörler arasında anlamlı farklılıklar olduğudur.

Emir ve Saraçli (2011) yaptıkları araştırmada, Yapısal Eşitlik Modellerini (SEM) kullanarak turistlerin termal turizmden memnuniyet düzeylerinin belirlenmesini amaçlamışlardır. Araştırmacılar, turistlerin memnuniyet düzeyini anlamak amacıyla, SPSS ve LISREL istatistik paket programlarını kullanarak veri setlerine, hem Keşfedici Faktör Analizi (EFA) hem de Doğrulayıcı Faktör Analizi (CFA) uygulamıştır. Keşfedici faktör analizinin bulgularına göre, turist memnuniyetinin beş faktörden oluştuğu belirlenmiştir. Analiz, turistlerin "Özel Birimlerin Temizliği" algısının "Özel Termal Birim" özellikleri üzerinde en büyük etkiye sahip olmasına rağmen, "Ek Hizmetleri" algısının, turistlerin memnuniyet düzeyindeki "Genel Fiziksel Özellikleri" üzerinde olduğunu göstermektedir.

Aymankuy, Akgül ve Akgül (2012) tarafından yapılan araştırmada 251 müşteriye anket uygulaması yapılmıştır. Bu araştırmaya göre Gönen'de termal işletmeleri tercih eden müşterilerin, genel olarak memnun olduğu sonucuna varılmıştır.

Öztürk ve Kenzhebayeva (2013) tarafından yapılan araştırmada, Türkiye ve Kazakistan'da faaliyette bulunan 4 ve 5 yıldızlı termal otel işletmelerinin hizmet kalitesine ilişkin müşteri memnuniyetinin belirlenmesi amaçlanmıştır. 191'i Türk, 193'üde Kazak müşteri olmak üzere 384müşteriye anket uygulaması yapılmıştır. Araştırmanın bulgularına göre, müşterilerin tatile çlkma sebebinin her iki ülke insanı için de en çok tedavi ve dinlenme amaciyla olduğu ifade edilmiştir. Kazaklar, Türklerin hiç tercih etmedikleri peloidterapi (Çamur Tedavisi) hizmetinden de yoğun olarak faydalandığı sonucuna varılmıştır. Araştırmada elde edilen diğer bir bulgu ise Kazakistan'daki termal turizme katılan müşterilerin Türkiye'deki müşterilere göre, seyahatlerinden daha fazla memnun olduklarıdır.

Boekstein ve Spencer (2013) tarafından yapılan araştırma, termal kaynakların sağlık turizmi kapsamında gelişim potansiyelini değerlendirmek amacıyla yapılmıştır. Güney Afrika Western Cape'de bulunan altı adet kaplıca merkezinde konaklayan 383 müşteriye anket uygulanmıştır. Elde edilen bulgulara göre, ziyaretçilerden bu kaplıcaları seçme nedenleri/etkinlik tercihlerine bağlı olarak, dört basamaktan oluşan, birbiriyle ilişkili kavramları cevaplamaları istenmiştir. Dört bölümden birinin hem sağllk hem de sağllk turizmi faaliyetlerine özel ilgi gösterdiği ve çoğu ziyaretçinin, etkinlik seçimi ile kaplıca tesislerindeki konaklamalarından ve önemli sağlık hizmetlerinden faydalandığı sonucuna ulaşılmıştır.

Borodulin, (2013) tarafından yapılan tez çalışmasında, Finlandiya'da Rantasipi Ikaalinen SPA'da müşteri memnuniyetinin durumu hakkında bilgi sağlamak ve mevcut hizmetlere, katma değer oluşturabilecek potansiyel ürünler için fikir toplamaktır. Araştırmada anket tekniğinden faydalanılmış ve 2013 yılının Şubat ve Mart aylarında kaplıcada konaklayan 59 kişiye anket uygulaması gerçekleştirilmiştir. Araştırmadan elde edilen bulgulara göre, Ikaalinen Kaplıcalarında konaklayan müşterilerin, verilen hizmetlerden son derece memnun olduğu ve ziyaretçilerin burayı tekrar ziyaret etme niyetlerinin olduğu sonucuna varılmıştır.

Aşık (2014) tarafından Balıkesir'in Bigadiç ilçesinde devre mülk sistemiyle hizmet veren termal turizm işletmelerinde konaklayan müşterilerin memnuniyet düzeylerini belirlemek amaciyla bir araştırma yapılmıştır. 190 müşteriye anket uygulaması gerçekleştirilmiştir. Araştırmada otelin sunduğu güvenlik hizmetleri dişında verilen hizmetlerden genel bir memnuniyetsizlik tespit edilmiştir. Bu müşteri memnuniyetsizliğinin nedenleri; Termal otelde boş zaman aktiviteleri yapmamak, işletmenin verdiği sözleri yerine getirmemek ve sorunları çözmemek olarak sıralanmıştır. "Hijyen ve fiyat" konularında ise memnuniyetin olduğu sonucuna varılmıştır. Araştırmada müşteri memnuniyetinin sağlanabilmesi için ise tesisin niteliklerinin iyileştirilmesi, 
tesiste rekreasyonel faaliyetlere yer verilmesi ve tesisin hizmet kalitesinin artırılmasıyla mümkün olacağ 1 belirtilmektedir.

Belber ve Turan (2015) tarafından yapılan araştırmada, Kırşehir'deki termal tesislerin durumuna değinilerek, Kırşehir'de termal turizm hizmeti veren işletmelerde konaklayan turistik tüketicilerin tatmin düzeylerine etki eden faktörlerin belirlenmesi amaciyla, termal tesislerde konaklayan turistik tüketicilere 295 anket uygulanmıştır. Elde edilen sonuçlara göre termal tesislerde konaklayan turistik tüketicilerin tatmin düzeylerinde, "süreç yönetimi", "tesis çalışanlarının niteliği", "tesisin nitelikleri" ve "yeniden satın alma ve önerme davranışları" faktörlerinin etkisinin olduğu ve bu faktörlerin tüketicilerin demografik özelliklerine göre farklılık gösterdiği belirlenmiştir.

Şahin ve Şen (2017) tarafından yapılan araştırmanın amacı, bir hizmet işletmesinde, hizmet kalitesi ile müşteri memnuniyeti arasındaki ilişkilerin incelenmesidir. Anket yönteminin kullanıldığı araştırmada, müşteri memnuniyeti ile hizmet kalitesinin tüm boyutları arasında olumlu ilişkiler olduğu, müşterilerin hizmet kalitesinin fiziksel özellikleri, güven algıları ve güvenilirliğin artmasının memnuniyet düzeylerini de artırdığı sonucuna varılmıştır.

Koskinen ve Wilska (2018) tarafından Finlandiya' da yapılan araştırmanın amacı, insanların genel olarak kaplıca ziyaretleri ve sağlık tüketimi ile ilgili davranışlarını etkileyen temel faktörleri incelemektir. Fin kaplıcalarında 298 ziyaretçiye internet üzerinden anket yöntemi uygulanmıştır. Araştırma bulgularına göre, çok farklı demografik profilleri olan Fin halkının sağlıklarına daha bütünsel bir yaklaşım gösterdiği sonucuna varılmıştır.

Karabacak (2019) tarafından yapılan tez çalışmasında, Samsun Havza'da ve Afyonkarahisar'da faaliyet gösteren termal işletmelerde konaklayan müşterilerin, hizmet kalite algılarını karşılaştırıp eksiklikleri tespit etmek ve elde edilen verilere göre öneriler geliştirmek amaçlanmıştır. Her iki termal işletmeye de 150'şer anket dağıtılmış, 248 anket değerlendirilmeye alınabilmiştir. Araştırmada, çalışana bakış açısı, müşteri ilişkileri, ön büro hizmetleri, kat hizmetleri ve yiyecek-içecek hizmet kalitesi faktörlerinde Havza'daki müşteriler Afyonkarahisar'daki müşterilere kıyasla kalite algılarının daha yüksek olduğu, her iki işletmede konaklayan müşterilerin havuz, hamam, sauna ve termal su kalitesinden aldıkları hizmetten memnun olduğu sonucuna ulaşılmıştır.

Yıldız (2020) tarafından Ankara Kızılcahamam'da hizmet veren termal turizm işletmelerini ziyaret eden müşterilerin müşteri memnuniyeti ve yaşam kalitesi algılarını ölçmek ve bu algıda demografik değişkenlere bağlı farklılık olup olmadığını ortaya çıkarmak amacıyla 384 müşteriye anket uygulaması yapılmıştır. Bulgulara göre termal turizmde müşteri memnuniyeti ve yaşam kalitesi algısının verilen hizmetin kalitesine göre farklılık gösterdiğini ortaya koymaktadır. Araştırmada demografik değişkenlere dayalı cinsiyet ve medeni durum değişkeninin müşteri memnuniyeti ve yaşam kalitesi algısını etkilemediği, yaş değişkeninin sadece yaşam kalitesi algısını etkilediği tespit edilmiştir. Eğitim değişkeninin ise sadece müşteri memnuniyetini etkilediği ortaya çıkmıştır. Gelir düzeyi değişkeninin ise hem müşteri memnuniyeti hem de yaşam kalitesi algısını etkilediği sonucuna ulaşılmıştır. Ayrıca tesise tedavi ve merak amacı ile gelenlerin dinlenme ve yenilenme amacı ile gelenlere kıyasla müşteri memnuniyeti ve yaşam kalitesi algisı daha olumlu olduğu tespit edilmiştir.

İncelenen tüm çalışmaların termal turizm alanında müşteri memnuniyeti ve müşteri memnuniyetini etkileyen faktörlerin neler olduğunun ortaya konulması ile yapıldığı görülmektedir. Yapılan bu çalışma ile literatürde ki yapılan diğer araştırmalar arasında benzerlik ve farklılıkların ortaya konulması amaçlanmaktadır. 


\section{YÖNTEM}

\section{Araştırmanın Problemi ve Hipotezleri}

Termal otel sektöründe otelde konaklayan müşteriyle doğrudan etkileşim içinde bulunan çalışanların müşterileri ağırlamada, müşterilere karşı nazik, güler yüzlü, sıcak ve samimi olmalarında hizmetleri zamanında sunmalarında, müşterilerin şikâyet ve istekleriyle ilgilenmede; aldığı eğitim seviyesi, deneyimi, fiziki görünümü, davranış biçimi müşteri memnuniyeti açısından çok önemlidir. Bu önem doğrultusunda müşteri kavramı, termal turizm hizmeti veren işletmelerin odak noktası haline gelmiştir. Termal işletmeler, "öncelik müşterinin istek ve beklentileridir" solaganıyla faaliyetlerini sürdürmektedir (Olcay ve Sürme, 2014: 837).

Termal otel işletmelerinin konaklama, yeme-içme ve rekreasyon hizmetlerinin yanı sıra şifa verici kaynaklara da sahip olması, müşterilerine avantajlar sağlamaktadır. Hizmet sektörü içerisinde önemli yere sahip olan termal otel işletmelerinde, sunulan hizmetin ölçülmesi ve müşteriler üzerindeki olumsuz ya da olumlu etkileri araştırmayı önemli kılmaktadır. Bu kapsamda Kahramanmaraş İli Onikişubat İlçesi Döngele Mahallesinde yer alan turizm işletme belgeli termal otel işletmelerinde konaklayan müşterilere, memnuniyet anketi uygulanmıştır. Burada bulunan otellerde konaklayan müşterilerin termal tesisi seçimlerindeki etkenlerin neler olduğu, termal turizm hizmetlerinin müşteri memnuniyeti açısından değerlendirilmesi, araştırmanın problemini oluşturmaktadır. Bu doğrultuda araştırmanın hipotezleri şunlardır:

H1: Müşterilerin memnuniyet düzeyleri yüksektir.

H2: Müşterilerin memnuniyet düzeyleri ile bazı demografik ve tanıtıcı özellikleri arasında anlamlı bir farklılık vardır.

\section{Araştırmanın Amacı ve Önemi}

Araştırmada, Kahramanmaraş İli, Onikişubat İlçesi sınırlarında (Döngele Kaplıcası) faaliyet gösteren otel işletmelerinin, termal turizm potansiyeli ve termal işletmeleri tercih eden müşterilerin konakladıkları işletmelerde verilen hizmet karşısında, müşterinin memnuniyet düzeylerinin ölçülmesi amaçlanmıştır.

Araştırma için bu bölgenin seçilme sebebi, nitelikli hizmet veren termal işletmelerin burada yoğunluk kazanması ve "turizm işletme belgeli" termal otellerin burada bulunuyor olmasıdır. Kahramanmaraş'ta faaliyet gösteren termal konaklama işletmelerinde coğrafi ve sağlık hizmetleri açısından birkaç araştırmacı tarafından çalışma yapılmasına karşın "turizm disiplini" içerinde yapılmış benzer bir çalışmanın olmayışı, alanyazına katkı sağlaması açısından önemlidir. Araştırma sonucunda, bulgular ışığında eksikliklerin giderilmesi hem yöredeki termal işletmelere hem de Kahramanmaraş termal turizmine yönelik katkı sağlaması bakımından önem taşımaktadır.

\section{Veri Toplama Aracı ve Süreci}

Araştırmada birincil veri toplama tekniklerinden anket yöntemi kullanılmıştır. Turizm işletme belgeli termal turizm işletmelerini tercih eden müşterilerin memnuniyetlerinin belirlenmesine yönelik olarak Esma Acayip (2012) ve Yalçın Keskin (2008) tarafından geliştirilen ölçekler yeniden düzenlenerek kullanılmıştır.

Anket soruları, Döngele Kaplıcalarında faaliyet gösteren termal otel işletmelerinde konaklayan müşterilere yöneltilmiştir. Anket formları, müşterilerin demografik bilgilerini belirlemesi ve 
memnuniyetlerini ortaya koyması açısından üç ayrı bölümden oluşmaktadır. Birinci bölümde, müşterilerin demografik özelliklerini belirmeye yönelik 5 soru bulunmaktadır. İkinci bölümde ise müşterilerin termal tesis ile ilgili müşterinin tercihleri hakkında 4 soruya yer verilmiştir. Son bölümde ise müşterilerin memnuniyet düzeylerini belirlemeye yönelik 43 soru bulunmaktadır.

\section{Uygulanan İstatiksel Yöntemler}

Bu araştırmada katılımcılara sunulan anket, 2020 yılının Kasım ve Aralık aylarında yüz yüze gerçekleştirilmiştir. Araştırmada kullanılan ölçeğin güvenilirlik analizi, Cronbach's Alfa katsayısı hesaplanarak yapılmıştır. Müşteri Memnuniyet Ölçeğinin güvenilirlik katsayısı 0,940'tır.

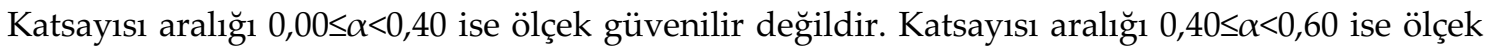
düşük güvenilirliktedir. Katsayısı aralığı $0,60 \leq \alpha<0,80$ ise ölçek oldukça güvenilir, katsayısı aralığ $0,80 \leq \alpha<1,00$ ise ölçek yüksek güvenilirliktedir (Kalayc1, 2009: 405; Aşık-Akşit, 2014: 112). Bu değerlendirmeye göre ölçek yüksek güvenilirdir.

Katılımcların memnuniyet düzeylerinin belirlenmesinde aritmetik ortalama ve standart sapma değerleri yorumlanmıştır. Anket sorularının daha iyi yorumlanabilmesi için ifadeler; "Kesinlikle Katılıyorum" ve "Kesinlikle Katılmıyorum" seçeneğinden başlamak üzere 5'ten 1'e doğru puanlanma yoluna gidilerek "Kesinlikle Katıllyorum" ve "Katılıyorum" seçenekleri için yüksek, "Ne Katılıyorum Ne Katılmıyorum" seçeneği ne yüksek ne düşük, "Katılmıyorum" ve "Kesinlikle Katılmıyorum" seçenekleri ise düşük olarak değerlendirilmiştir.

Araştırmada Müşteri Memnuniyeti Ölçeğinin normallik dağılımlarını belirlemek için Kolmogrov-Simirnov Testi uygulanmış ve elde edilen sonuçlar Tablo 2'de gösterilmiştir. Normallik testi sonucunda Kolmogrov-Smirnov Testi ile verilerin Basıklık ve Çarpıklık değerlerinin +2 ile -2 arasında olmadığı belirlenmiştir. Tüm bu testler sonucunda ölçeklerin dağılımının normal dağılıma uygun olmadığı görülmüştür. Müşteri Memnuniyet Ölçeği veri setinin Çarpıklık Değeri -5,733, Basıklık Değeri 3,905, olduğu görülmektedir.

Tablo 2. Müşteri Memnuniyeti Ölçeği Veri Seti Normallik Dağılım Tablosu

\begin{tabular}{|l|c|}
\hline Uygulama & Sonuç \\
\hline Basıklık Değeri & 3,905 \\
\hline Çarpıklık Değeri & $-5,733$ \\
\hline Kolmogrow-Smirnov (K-S) Testi & $\leq, 000$ \\
\hline
\end{tabular}

\section{Araştırma Evreni ve Örneklemi}

$\mathrm{Bu}$ araştırmanın evrenini, Kahramanmaraş illinde bulunan turizm işletme belgeli termal otel işletmelerinde konaklayan müşteriler oluşturmaktadır. Kahramanmaraş İlinde turizm işletme belgeli termal oteller Onikişubat İlçesi, Döngele Kaplıcalarında bulunan "Orkis Palace Termal Otel" ve "Tatlısu Termal Otel" müşterileri, araştırmanın örneklemini oluşturmaktadır.

Araştırmada termal otellerde konaklayan 520 müşteriye yüz yüze anket uygulaması yapılmıştır. Araştırma kapsamında otel işletmelerinin genel müdürleriyle görüşülerek izin alınmış ve anket, müşterilerle yüz yüze yapılmıştır. Anketlerin 82 'si eksik ya da yanlış doldurulduğundan değerlendirilme dışı bırakılmış ve 438 anket üzerinden değerlendirilmiştir. 


\section{BULGULAR}

\section{Demografik Yapıya ve Müşteri Tercihlerine İlişkin Bulgular}

Araştırmaya katılan çalışanların demografik özelliklerini tespitinde; yaş, cinsiyet, eğitim durumu, aylık ortalama geliri ve daha önce bu otelde konaklama yapıp yapmadıkları olmak üzere sorular sorulmuş ve elde edilen bulgulara ait frekans ve yüzde değerleri Tablo 3'te verilmiştir.

Tablo 3. Araştırmaya Katılan Termal Otel Müşterilerinin Demografik ve Tanıtıcı Özelliklerine İlişkin Frekans ve Yüzde Analizi Bulguları

\begin{tabular}{|c|c|c|c|}
\hline Değişkenler & & $\mathbf{N}$ & $\%$ \\
\hline \multirow{6}{*}{ Yaş } & $18-25$ & 18 & 11 \\
\hline & $26-33$ & 78 & 17,8 \\
\hline & $34-41$ & 89 & 20,3 \\
\hline & $42-49$ & 93 & 21,2 \\
\hline & $50-57$ & 67 & 15,3 \\
\hline & 58 ve Üzeri & 63 & 14,4 \\
\hline \multirow{2}{*}{ Cinsiyet } & Kadın & 195 & 44,5 \\
\hline & Erkek & 243 & 55,5 \\
\hline \multirow{5}{*}{ Eğitim Düzeyi } & İlkokul & 77 & 17,6 \\
\hline & Ortaokul & 104 & 23,7 \\
\hline & Lise & 133 & 30,4 \\
\hline & Önlisans & 66 & 15,1 \\
\hline & Lisans ve Üzeri & 58 & 13,2 \\
\hline \multirow{3}{*}{ Aylık Ortama Gelir } & 1001-2500TL & 100 & 22,8 \\
\hline & 2501-4000TL & 171 & 39 \\
\hline & 4001 TL ve Üzeri & 167 & 38,1 \\
\hline
\end{tabular}

Buna göre en fazla müşterinin $42-49$ yaş Aralığında $(\% 21,2)$ olduğu; müşterilerin yarıdan fazlasının $(\% 55,5)$ erkek müşterilerden oluştuğu; eğitim verilerine göre en fazla müşterinin $(\% 30,4)$ lise mezunu olduğu; en fazla aylık ortalama gelire sahip müşterinin 2501-4000 TL aralığında (\%39) olduğu tespit edilmiştir.

\section{Müşterilerin Memnuniyet Düzeylerinin Belirlenmesine İlişkin Bulguları}

Bu kısımda anket uygulamasına katılan 438 termal otel müşterisinin anket formunda yer alan ifadelerin aritmetik ortalamaları, standart sapma ve sonuç değerleri Tablo 4 'de verilerek müşterilerin termal otelden memnuniyet düzeylerinin belirlenmesi amaçlanmıştır. 
Tablo 4. Müşterilerin Memnuniyet Ölçeğine İlişkin Aritmetik Ortalama, Standart Sapma Değerleri ile Sonuç Bulguları

\begin{tabular}{|c|c|c|c|c|}
\hline $\begin{array}{c}\text { M. } \\
\text { Memnuniyet } \\
\text { Boyutları }\end{array}$ & İfadeler & A.O. $\bar{x}$ & S.S & Sonuç \\
\hline \multirow{10}{*}{$\begin{array}{c}\text { Otel } \\
\text { Memnuniyeti } \\
\text { (Faktör 1) }\end{array}$} & Otelin, modern görünümlü donanım ve malzemeleri vardır. & 4,16 & 0,81 & Yüksek \\
\hline & $\begin{array}{l}\text { Otelin genel görünüşü ve atmosferi hoş bir etki } \\
\text { bırakmaktadır. }\end{array}$ & 4,13 & 0,86 & Yüksek \\
\hline & Otelin oda dizaynları uygun ve rahattır. & 4,16 & 0,81 & Yüksek \\
\hline & Otelin sunduğu hizmetin çeşitliliği vardır. & 4,15 & 0,92 & Yüksek \\
\hline & $\begin{array}{l}\text { Otele ilişkin hizmetleri gösteren materyaller (broşür/ilanlar } \\
\text { vb.) açılayıcıdır. }\end{array}$ & 4,09 & 1,04 & Yüksek \\
\hline & Otelin oda manzaraları etkileyicidir. & 4,13 & 0,98 & Yüksek \\
\hline & Otelin oda donanımları dinlenme için uygundur. & 4,21 & 0,80 & Yüksek \\
\hline & Otelin oda isıları mevsime uygundur. & 4,02 & 0,95 & Yüksek \\
\hline & Otelin teknik donanımı (klima, TV vb.) yeterlidir. & 4,04 & 0,96 & Yüksek \\
\hline & Otelde temizlik ve hijyen kurallarına uyulmaktadır. & 4,49 & 0,83 & Yüksek \\
\hline \multirow{10}{*}{$\begin{array}{c}\text { Termal Tesis } \\
\text { Memnuniyeti } \\
\text { (Faktör 2) }\end{array}$} & Otelin konaklama fiyatları uygundur. & 3,97 & 1,14 & Yüksek \\
\hline & Otelin yiyecek-içecek fiyatları uygundur. & 3,84 & 1,23 & Yüksek \\
\hline & Otele ulaşım ücreti uygundur. & 3,66 & 1,33 & Yüksek \\
\hline & $\begin{array}{l}\text { Otelin termal su kaynaklarından yeterli düzeyde } \\
\text { yararlandım. }\end{array}$ & 4,32 & 0,84 & Yüksek \\
\hline & $\begin{array}{l}\text { Otelin termal su kaynaklarından yeterli düzeyde fayda } \\
\text { gördüm. }\end{array}$ & 3,94 & 1,11 & Yüksek \\
\hline & Otelin şikâyetlere karşı duyarlılığı yeterlidir. & 3,74 & 1,21 & Yüksek \\
\hline & Genel olarak otelden memnun kaldım. & 4,02 & 1,03 & Yüksek \\
\hline & Kaldığım termal tesisi tekrar tercih ederim. & 3,76 & 1,28 & Yüksek \\
\hline & Kaldığım termal tesisi başkalarına tavsiye ederim. & 3,70 & 1,33 & Yüksek \\
\hline & $\begin{array}{l}\text { Aynı tatmin başka tesisten sağlanacağını bilsem de bu tesisi } \\
\text { tercih ederim. }\end{array}$ & 3,51 & 1,48 & Yüksek \\
\hline \multirow{5}{*}{$\begin{array}{c}\text { Personel } \\
\text { Memnuniyeti } \\
\text { (Faktör 3) }\end{array}$} & Otel çalışanları müşterilerle ilgilenmektedir. & 4,39 & 0,72 & Yüksek \\
\hline & Otel çalışanlarının fiziki görünümleri düzgündür. & 3,95 & 1,01 & Yüksek \\
\hline & $\begin{array}{l}\text { Otel çalışanları müşterilerine sunacakları hizmetleri } \\
\text { zamanında sunmaktadır. }\end{array}$ & 4,16 & 0,94 & Yüksek \\
\hline & Otel çalışanları müşterilerine karşı naziktir. & 4,26 & 0,89 & Yüksek \\
\hline & $\begin{array}{l}\text { Otel çalışanları müşterilere karşı güler yüzlü, sıcak ve } \\
\text { samimi davranmaktadır. }\end{array}$ & 4,18 & 0,92 & Yüksek \\
\hline \multirow{4}{*}{$\begin{array}{l}\text { Çalışanların } \\
\text { Tutumu } \\
\text { (Faktör 4) }\end{array}$} & $\begin{array}{l}\text { Otel çalışanlarının davranışları müşterilere güven } \\
\text { vermektedir. }\end{array}$ & 3,90 & 1,01 & Yüksek \\
\hline & Otel çalışanları yardımseverdir. & 3,98 & 0,96 & Yüksek \\
\hline & $\begin{array}{l}\text { Otel çalışanları müşterisine yardımcı olmakta her zaman } \\
\text { isteklidir. }\end{array}$ & 3,71 & 1,16 & Yüksek \\
\hline & $\begin{array}{l}\text { Otel çalışanları müşterilerin isteklerini karşılamaya her } \\
\text { zaman hazırdırlar. }\end{array}$ & 3,67 & 1,16 & Yüksek \\
\hline \multirow{4}{*}{$\begin{array}{c}\text { Tesis } \\
\text { Olanakları } \\
\text { (Faktör5) }\end{array}$} & Otelde spor etkinlikleri yeterlidir. & 3,87 & 1,03 & Yüksek \\
\hline & Otelin eğlence hizmetleri yeterlidir. & 3,94 & 1,05 & Yüksek \\
\hline & Otelde yürüyüş parkurları bulunmaktadır. & 3,31 & 1,51 & $\begin{array}{l}\text { Ne Yüksek Ne } \\
\text { Düşük }\end{array}$ \\
\hline & Otelin sağlık hizmetleri yeterlidir. & 3,67 & 1,31 & Yüksek \\
\hline \multirow{3}{*}{$\begin{array}{l}\text { Fiziksel Yapı } \\
\text { (Faktör 6) }\end{array}$} & Otel içerisindeki aydınlatma yeterlidir. & 4,29 & 1,80 & Yüksek \\
\hline & Otelin güvenlik sistemleri yeterlidir. & 4,48 & 0,79 & Yüksek \\
\hline & Otelin elektrik ve su sistemi yeterlidir. & 4,41 & 0,80 & Yüksek \\
\hline \multirow{2}{*}{$\begin{array}{c}\text { İklimsel } \\
\text { Memnuniyet } \\
\text { (Faktör 7) }\end{array}$} & Otelin bulunduğu bölgede iklim güzeldir. & 4,01 & 1,19 & Yüksek \\
\hline & Otelin bulunduğu çevre doğal bir güzelliğe sahiptir. & 4,34 & 0,94 & Yüksek \\
\hline \multicolumn{2}{|c|}{ Memnuniyet Ölçeği Genel Ortalama } & 4,01 & 1,05 & Yüksek \\
\hline
\end{tabular}


Buna göre, müşterilerin memnuniyet düzeylerini belirlemeye yönelik soruların genel aritmetik ortalamalarına bakıldığında; "Yüksek" ve "Ne Yüksek Ne Düşük" şeklinde olduğu görülmektedir.

Tablo 4'e göre müşterilerin memnuniyet düzeylerinin yüksek olduğu ifadeler; “Otelin, modern

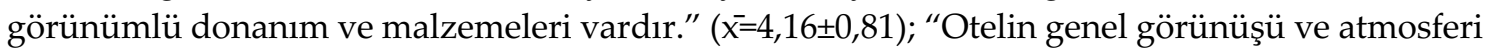
hoş bir etki bırakmaktadır." ( $\bar{x}=4,13 \pm 0,86)$; "Otelin oda dizaynları uygun ve rahattır." $(\bar{x}=4,16 \pm 0,81)$; "Otelin sunduğu hizmetin çeşitliliği vardır." ( $\bar{x}=4,15 \pm 0,92)$; "Otele ilişkin hizmetleri gösteren materyaller (broşür/ilanlar vb.) açılayıcıdır." ( $\bar{x}=4,09 \pm 1,04)$; "Otelin oda manzaraları etkileyicidir." $(x=4,13 \pm 0,98)$; "Otelin oda donanımları dinlenme için uygundur." $(\bar{x}=4,21 \pm 0,80)$; "Otelin oda 1sıları mevsime uygundur." $(\bar{x}=4,02 \pm 0,95)$; "Otelin teknik donanımı (klima, TV vb.) yeterlidir." ( $\bar{x}=4,04 \pm 0,96)$; "Otelde temizlik ve hijyen kurallarına uyulmaktadır." ( $\bar{x}=4,49 \pm 0,83)$; "Otelin konaklama fiyatları uygundur." $(\bar{x}=3,97 \pm 1,14)$; "Otelin yiyecek-içecek fiyatları

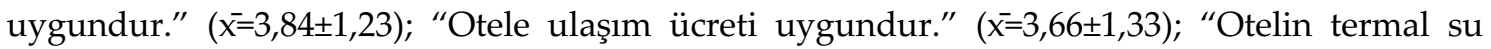
kaynaklarından yeterli düzeyde yararlandım." ( $\bar{x}=4,32 \pm 0,84)$; “Otelin termal su kaynaklarından

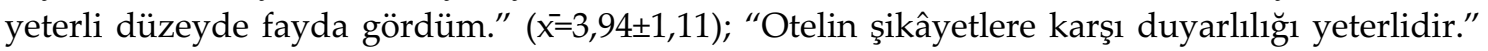
( $\bar{x}=3,74 \pm 1,21)$; "Genel olarak otelden memnun kaldım." ( $\bar{x}=4,02 \pm 1,03)$; "Kaldığım termal tesisi

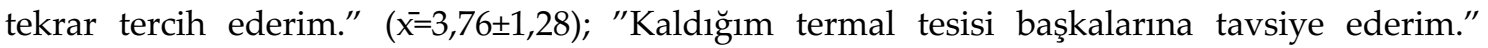
$(\bar{x}=3,70 \pm 1,33)$; "Aynı tatmin başka tesisten sağlanacağını bilsem de bu tesisi tercih ederim." $(\bar{x}=3,51 \pm 1,48)$; "Otel çalışanları müşterilerle ilgilenmektedir." $(\bar{x}=4,39 \pm 0,72)$; "Otel çalışanlarının fiziki görünümleri düzgündür." ( $\bar{x}=3,95 \pm 1,01)$; "Otel çalışanları müşterilerine sunacakları hizmetleri zamanında sunmaktadır." ( $\mathrm{x}=4,16 \pm 0,94)$; "Otel çalışanları müşterilerine karşı naziktir." ( $\bar{x}=4,26 \pm 0,89)$; "Otel çalışanları müşterilere karşı güler yüzlü, sıcak ve samimi davranmaktadır." $(\bar{x}=4,18 \pm 0,92)$; "Otel çalışanlarının davranışları müşterilere güven vermektedir." ( $\bar{x}=3,90 \pm 1,01)$; "Otel çalışanları yardımseverdir." ( $\overline{x=3,98 \pm 0,96) ; ~ " O t e l ~ c ̧ a l ı s ̧ a n l a r ı ~ m u ̈ s ̧ t e r i s i n e ~ y a r d ı m c ı ~ o l m a k t a ~}$ her zaman isteklidir." ( $\bar{x}=3,71 \pm 1,16)$; "Otel çalışanları müşterilerin isteklerini karşılamaya her zaman hazırdırlar." ( $\bar{x}=3,67 \pm 1,16)$; "Otelde spor etkinlikleri yeterlidir." ( $\bar{x}=3,87 \pm 1,03)$; "Otelin eğlence hizmetleri yeterlidir." ( $\mathrm{x}=3,94 \pm 1,05)$; "Otelin sağlik hizmetleri yeterlidir." ( $\mathrm{x}=3,67 \pm 1,31)$; "Otel içerisindeki aydınlatma yeterlidir." ( $\bar{x}=4,29 \pm 1,80)$; "Otelin güvenlik sistemleri yeterlidir." $(\bar{x}=4,48 \pm 0,79)$; "Otelin elektrik ve su sistemi yeterlidir." ( $\bar{x}=4,41 \pm 0,80)$; “Otelin bulunduğu bölgede iklim güzeldir." $(\bar{x}=4,01 \pm 1,19)$; “Otelin bulunduğu çevre doğal bir güzelliğe sahiptir." ( $\mathrm{x}=4,34 \pm 0,94)$ şeklindedir. Müşterilerin Memnuniyet düzeylerinin ne yüksek ne düşük olarak ifade edildiği önerme ise, "Otelde yürüyüş parkurları bulunmaktadır." $(\bar{x}=3,31 \pm 1,51)$ şeklindedir.

Tablo 4'e göre memnuniyet ölçeği genel ortalama ve standart sapma değerleri $\bar{x}=4,01 \pm 1,05^{\prime}$ tir. Buna göre müşterilerin memnuniyet düzeylerinin yüksek olduğu görülmektedir. Bu sonuçlara göre araştırmanın "Müşterilerin memnuniyet düzeyleri yüksektir" H1 hipotezi kabul edilmiştir.

\section{Bağımsız Değişkenlere İlişkin Bulgular}

Çalışmanın bu kısmında memnuniyet ölçeği veri seti normal dağılım göstermediğinden, iki değişkene sahip gruplar için parametrik olmayan testlerden Mann-Whitney U Testi, daha fazla değişkene sahip gruplar için ise Kruskal-Wallis H Sıralar Analizi Testi uygulanmıştır.

\section{Termal Otel İşletmelerinde Konaklayan Müş̧terilerin Yaşları ile Müşteri Memnuniyeti Arasındaki Farklılaşma Durumu}

Kahramanmaraş İli Onikişubat İlçesi sınırları içerisinde Döngele Mahallesinde faaliyet gösteren turizm işletme belgeli termal otel işletmelerinde konaklayan müşterilerin memnuniyetleri ile 
yaşları arasındaki ilişkiye göre $\% 5$ anlamlılık düzeyinde bir farklılık gösterip göstermediğini anlamak amacıyla Kruskal Wallis H Testi uygulanmış ve elde edilen bulgular Tablo 5'de verilmiştir.

Tablo 5. Termal Otel İşletmelerinde Konaklayan Müşterilerin Memnuniyetleri ile Müşterilerin Yaşları Arasındaki İlişki

\begin{tabular}{|c|c|c|c|c|c|}
\hline $\begin{array}{l}\text { Müssteri Memnuniyet } \\
\text { Boyutları }\end{array}$ & İfadeler & $\mathbf{N}$ & $\begin{array}{c}\text { Sira } \\
\text { Ortalaması }\end{array}$ & $\begin{array}{r}\text { Kruskal } \\
\text { Wallis H }\end{array}$ & p \\
\hline \multirow{6}{*}{$\begin{array}{l}\text { Otel Memnuniyeti } \\
\text { (Faktör 1) }\end{array}$} & $18-25$ & 48 & 219,54 & \multirow{6}{*}{6,221} & \multirow{6}{*}{0,285} \\
\hline & $26-33$ & 78 & 206,22 & & \\
\hline & $34-41$ & 89 & 236,57 & & \\
\hline & $42-49$ & 93 & 234,05 & & \\
\hline & $50-57$ & 67 & 204,25 & & \\
\hline & 58 ve Üzeri & 63 & 206,54 & & \\
\hline \multirow{6}{*}{$\begin{array}{l}\text { Termal Tesis Memnuniyeti } \\
\text { (Faktör 2) }\end{array}$} & $18-25$ & 48 & 267,36 & \multirow{6}{*}{18,496} & \multirow{6}{*}{0,002} \\
\hline & $26-33$ & 78 & 236,90 & & \\
\hline & $34-41$ & 89 & 227,64 & & \\
\hline & $42-49$ & 93 & 218,19 & & \\
\hline & $50-57$ & 67 & 184,07 & & \\
\hline & 58 ve Üzeri & 63 & 189,60 & & \\
\hline \multirow{6}{*}{$\begin{array}{l}\text { Personel Memnuniyeti } \\
\text { (Faktör 3) }\end{array}$} & $18-25$ & 48 & 232,41 & \multirow{6}{*}{4,623} & \multirow{6}{*}{0,464} \\
\hline & $26-33$ & 78 & 210,76 & & \\
\hline & 34-41 & 89 & 228,15 & & \\
\hline & $42-49$ & 93 & 212,64 & & \\
\hline & $50-57$ & 67 & 202,06 & & \\
\hline & 58 ve Üzeri & 63 & 236,94 & & \\
\hline \multirow{6}{*}{$\begin{array}{c}\text { Çalışanların Tutumu } \\
\text { (Faktör 4) }\end{array}$} & $18-25$ & 48 & 233,49 & \multirow{6}{*}{8,000} & \multirow{6}{*}{0,156} \\
\hline & $26-33$ & 78 & 227,06 & & \\
\hline & 34-41 & 89 & 235,92 & & \\
\hline & $42-49$ & 93 & 216,93 & & \\
\hline & $50-57$ & 67 & 185,62 & & \\
\hline & 58 ve Üzeri & 63 & 216,11 & & \\
\hline \multirow{6}{*}{$\begin{array}{l}\text { Tesis Olanakları } \\
\quad \text { (Faktör 5) }\end{array}$} & $18-25$ & 48 & 262,72 & \multirow{6}{*}{14,152} & \multirow{6}{*}{0,015} \\
\hline & $26-33$ & 78 & 241,21 & & \\
\hline & 34-41 & 89 & 223,12 & & \\
\hline & $42-49$ & 93 & 209,22 & & \\
\hline & $50-57$ & 67 & 196,06 & & \\
\hline & 58 ve Üzeri & 63 & 194,68 & & \\
\hline \multirow{6}{*}{$\begin{array}{l}\text { Fiziksel Yapı } \\
\text { (Faktör 6) }\end{array}$} & $18-25$ & 48 & 217,61 & \multirow{6}{*}{3,504} & \multirow{6}{*}{0,623} \\
\hline & $26-33$ & 78 & 218,21 & & \\
\hline & $34-41$ & 89 & 205,14 & & \\
\hline & $42-49$ & 93 & 237,27 & & \\
\hline & $50-57$ & 67 & 216,59 & & \\
\hline & 58 ve Üzeri & 63 & 219,67 & & \\
\hline \multirow{6}{*}{$\begin{array}{c}\text { İklimsel Memnuniyet } \\
\text { (Faktör 7) }\end{array}$} & $18-25$ & 48 & 194,85 & \multirow{6}{*}{5,496} & \multirow{6}{*}{0,358} \\
\hline & $26-33$ & 78 & 216,30 & & \\
\hline & 34-41 & 89 & 238,55 & & \\
\hline & $42-49$ & 93 & 218,34 & & \\
\hline & $50-57$ & 67 & 207,30 & & \\
\hline & 58 ve Üzeri & 63 & 230,02 & & \\
\hline
\end{tabular}


Buna göre müşterilerin "Otel Memnuniyeti", "Personel Memnuniyeti", "çalışanların tutumu", "fiziksel yapı" ve "iklimsel memnuniyet" faktörlerinde anlamlı bir farklılık olmadığ görülmüştür $(p>0,05)$. "Termal tesis memnuniyeti" ve "tesis olanakları" faktörlerinde anlamlı bir farklılık olduğu görülmektedir $(\mathrm{p}<0,05)$. Araştırmada beş faktörün anlamsız, iki faktörün anlamlı olduğu tespit edilmiştir. Bununla birlikte faktörlerin genel anlamlllık düzeyine bakıldığında da müşterilerin memnuniyet düzeyleri ile yaşlarına göre anlamlı bir farklılığın olmadığı görülmüştür $(p>0,05)$. Müşterilerin yaş değişkeninin, memnuniyet düzeyleri üzerinde etkili olmadığını söylemek mümkündür.

\section{Termal Otel İşletmelerinde Konaklayan Müşterilerin Cinsiyetleri ile Müşteri Memnuniyeti Arasındaki Farklılaşma Durumu}

Çalışmaya katılan termal otel işletmelerinde konaklayan müşterilerin memnuniyet düzeyleri ile cinsiyetleri arasında, \%5 anlamlılık düzeyinde bir farklılık olup olmadığını anlamak amacıyla Mann-Whitney U Testi uygulanmış ve elde edilen bulgular Tablo 8'deverilmiştir.

Tablo 6. Termal Otel İşletmelerinde Konaklayan Müşterilerin Cinsiyetleri ile Müşteri Memnuniyeti Arasındaki Farklılaşma Durumu

\begin{tabular}{|c|c|c|c|c|c|c|}
\hline $\begin{array}{l}\text { Müsteri Memnuniyet } \\
\text { Boyutları }\end{array}$ & Cinsiyet & $\mathbf{n}$ & Sira Ortalaması & M.W.U. & $\mathrm{Z}$ & $\mathrm{p}$ \\
\hline \multirow[t]{2}{*}{ Otel Memnuniyeti } & Kadın & 195 & 232,09 & \multirow{2}{*}{21237,500} & \multirow{2}{*}{$-2,013$} & \multirow{2}{*}{0,044} \\
\hline & Erkek & 243 & 209,40 & & & \\
\hline \multirow[t]{2}{*}{ Termal Tesis Memnuniyeti } & Kadın & 195 & 222,78 & \multirow{2}{*}{23053,000} & \multirow{2}{*}{$-0,500$} & \multirow{2}{*}{0,617} \\
\hline & Erkek & 243 & 216,87 & & & \\
\hline \multirow[t]{2}{*}{ Personel Memnuniyeti } & Kadın & 195 & 228,29 & \multirow{2}{*}{21979,000} & \multirow{2}{*}{$-1,395$} & \multirow{2}{*}{0,163} \\
\hline & Erkek & 243 & 212,45 & & & \\
\hline \multirow[t]{2}{*}{ Çalışanların Tutumu } & Kadın & 195 & 228,83 & \multirow{2}{*}{21872,500} & \multirow{2}{*}{$-1,453$} & \multirow{2}{*}{0,146} \\
\hline & Erkek & 243 & 212,01 & & & \\
\hline \multirow[t]{2}{*}{ Tesis Olanakları } & Kadın & 195 & 212,45 & \multirow{2}{*}{22318,500} & \multirow{2}{*}{$-1,077$} & \multirow{2}{*}{0,282} \\
\hline & Erkek & 243 & 225,15 & & & \\
\hline \multirow[t]{2}{*}{ Fiziksel Yap1 } & Kadın & 195 & 214,69 & \multirow{2}{*}{22754,000} & \multirow{2}{*}{$-0,766$} & \multirow{2}{*}{0,444} \\
\hline & Erkek & 243 & 223,36 & & & \\
\hline \multirow[t]{2}{*}{ İklimsel Memnuniyet } & Kadın & 195 & 216,25 & \multirow{2}{*}{23059,500} & \multirow{2}{*}{$-0,507$} & \multirow{2}{*}{0,612} \\
\hline & Erkek & 243 & 222,10 & & & \\
\hline
\end{tabular}

Buna göre cinsiyet değişkeni ile müşterilerin memnuniyet düzeyleri arasında "otel memnuniyeti" faktöründe anlamlı bir farklılık tespit edilirken $(p<0,05)$, "termal tesis memnuniyeti", "personel memnuniyeti", "çalışanların tutumu", "tesis olanakları", "fiziksel yapı" ve "iklimsel memnuniyet" faktörlerinde anlamlı bir farklılık tespit edilememiştir ( $p>0,05)$. Müşterilerin cinsiyet değişkeninin, memnuniyet düzeyleri üzerinde etkili olmadığını söylemek mümkündür. 


\section{Termal Otel İşletmelerinde Konaklayan Müşterilerin Eğitim Durumları ile Müşteri Memnuniyeti Arasındaki Farklılaşma Durumu}

Termal otel işletmelerinde konaklayan müşterilerin memnuniyet düzeyleri ile eğitim durumları arasında, \%5 anlamlılık düzeyinde bir farklılık olup olmadığını anlamak amacıyla Kruskal Wallis $\mathrm{H}$ Testi uygulanmış ve elde edilen bulgular Tablo 7'de verilmiştir.

Tablo 7. Termal Otel İşletmelerinde Konaklayan Müşterilerin Eğitim Durumları ile Müşteri Memnuniyeti Arasındaki Farklılaşma Durumu

\begin{tabular}{|c|c|c|c|c|c|}
\hline $\begin{array}{l}\text { Müşteri } \\
\text { Memnuniyet } \\
\text { Boyutları }\end{array}$ & İfadeler & $\mathbf{n}$ & $\begin{array}{c}\text { Sira } \\
\text { Ortalaması }\end{array}$ & $\begin{array}{l}\text { Kruskal } \\
\text { Wallis H }\end{array}$ & $\mathrm{p}$ \\
\hline \multirow{5}{*}{$\begin{array}{l}\text { Otel Memnuniyeti } \\
\text { (Faktör 1) }\end{array}$} & İlkokul & 77 & 207,05 & \multirow{5}{*}{11,096} & \multirow{5}{*}{0,026} \\
\hline & Ortaokul & 104 & 229,23 & & \\
\hline & Lise & 133 & 231,57 & & \\
\hline & Önlisans & 66 & 231,27 & & \\
\hline & Lisans ve Üzeri & 58 & 177,51 & & \\
\hline \multirow{5}{*}{$\begin{array}{l}\text { Termal Tesis } \\
\text { Memnuniyeti } \\
\text { (Faktör 2) }\end{array}$} & İlkokul & 77 & 212,01 & \multirow{5}{*}{4,710} & \multirow{5}{*}{0,318} \\
\hline & Ortaokul & 104 & 229,67 & & \\
\hline & Lise & 133 & 226,45 & & \\
\hline & Ön lisans & 66 & 223,66 & & \\
\hline & Lisans ve Üzeri & 58 & 190,53 & & \\
\hline \multirow{5}{*}{$\begin{array}{l}\text { Personel } \\
\text { Memnuniyeti } \\
\text { (Faktör 3) }\end{array}$} & İlkokul & 77 & 241,25 & \multirow{5}{*}{11,473} & \multirow{5}{*}{0,022} \\
\hline & Ortaokul & 104 & 219,65 & & \\
\hline & Lise & 133 & 231,43 & & \\
\hline & Ön lisans & 66 & 204,42 & & \\
\hline & Lisans ve Üzeri & 58 & 180,16 & & \\
\hline \multirow{5}{*}{$\begin{array}{l}\text { Çalışanların } \\
\text { Tutumu } \\
\text { (Faktör 4) }\end{array}$} & İlkokul & 77 & 239,58 & \multirow{5}{*}{8,401} & \multirow{5}{*}{0,078} \\
\hline & Ortaokul & 104 & 231,99 & & \\
\hline & Lise & 133 & 214,97 & & \\
\hline & Önlisans & 66 & 216,33 & & \\
\hline & Lisans ve Üzeri & 58 & 184,45 & & \\
\hline \multirow{5}{*}{$\begin{array}{l}\text { Tesis Olanakları } \\
\text { (Faktör 5) }\end{array}$} & İlkokul & 77 & 205,11 & \multirow{5}{*}{16,095} & \multirow{5}{*}{0,003} \\
\hline & Ortaokul & 104 & 233,61 & & \\
\hline & Lise & 133 & 234,00 & & \\
\hline & Önlisans & 66 & 232,04 & & \\
\hline & Lisans ve Üzeri & 58 & 165,79 & & \\
\hline \multirow{5}{*}{$\begin{array}{l}\text { Fiziksel Yap1 } \\
\text { (Faktör 6) }\end{array}$} & İlkokul & 77 & 221,04 & \multirow{5}{*}{6,781} & \multirow{5}{*}{0,148} \\
\hline & Ortaokul & 104 & 236,20 & & \\
\hline & Lise & 133 & 225,88 & & \\
\hline & Önlisans & 66 & 195,80 & & \\
\hline & Lisans ve Üzeri & 58 & 199,85 & & \\
\hline \multirow{5}{*}{$\begin{array}{l}\text { İklimsel } \\
\text { Memnuniyet } \\
\text { (Faktör 7) }\end{array}$} & İlkokul & 77 & 193,61 & \multirow{5}{*}{18,615} & \multirow{5}{*}{0,001} \\
\hline & Ortaokul & 104 & 214,43 & & \\
\hline & Lise & 133 & 252,41 & & \\
\hline & Önlisans & 66 & 221,88 & & \\
\hline & Lisans ve Üzeri & 58 & 184,78 & & \\
\hline
\end{tabular}


Müşterilerin eğitim değişkeni ile memnuniyet düzeylerine göre "termal tesis memnuniyeti", "çalışanların tutumu" ve "fiziksel yapı" faktörlerinde anlamlı bir farklılığın olmadığı tespit edilirken ( $p>0,05)$, "Otel Memnuniyeti", "Personel Memnuniyeti", "Tesis Olanakları" ve "İklimsel Memnuniyet" faktörlerinde ise anlamlı bir farklılığın olduğu tespit edilmiştir $(p<0,05)$. Müşterilerin eğitim değişkeninin, memnuniyet düzeyleri üzerinde etkili olduğunu söylemek mümkündür.

\section{Termal Otel İşletmelerinde Konaklayan Müşterilerin Aylık Ortalama Gelirleri ile Müşteri Memnuniyeti Arasındaki Farklılaşma Durumu}

Araştırmaya katılan termal otel işletmelerinde konaklayan müşterilerin aylık ortalama gelirleriyle memnuniyet düzeyleri arasında, \%5 anlamlılık düzeyinde bir farklılık olup olmadığını anlamak amacıyla Kruskal Wallis H Testi uygulanmış ve elde edilen bulgular Tablo 8 'de verilmiştir.

Tablo 8. Termal Otel İşletmelerinde Konaklayan Müşterilerin Aylık Ortalama Gelirleri ile Müşteri Memnuniyeti Arasındaki Durum

\begin{tabular}{|c|c|c|c|c|c|}
\hline $\begin{array}{c}\text { Müşteri Memnuniyet } \\
\text { Boyutları }\end{array}$ & İfadeler & $\mathbf{N}$ & $\begin{array}{c}\text { Sira } \\
\text { Ortalaması }\end{array}$ & $\begin{array}{l}\text { Kruskal } \\
\text { Wallis H }\end{array}$ & $\mathbf{p}$ \\
\hline \multirow{3}{*}{$\begin{array}{l}\text { Otel Memnuniyeti } \\
\text { (Faktör 1) }\end{array}$} & $1001-2500 \mathrm{TL}$ & 100 & 228,87 & \multirow{3}{*}{7,988} & \multirow{3}{*}{0,018} \\
\hline & $2501-4000 \mathrm{TL}$ & 171 & 233,60 & & \\
\hline & 4001 TL ve Üzeri & 167 & 199,46 & & \\
\hline \multirow{3}{*}{$\begin{array}{l}\text { Termal Tesis Memnuniyeti } \\
\text { (Faktör 2) }\end{array}$} & $1001-2500 \mathrm{TL}$ & 100 & 266,43 & \multirow{3}{*}{28,442} & \multirow{3}{*}{0,000} \\
\hline & $2501-4000 \mathrm{TL}$ & 171 & 226,10 & & \\
\hline & 4001 TL ve Üzeri & 167 & 184,64 & & \\
\hline \multirow{3}{*}{$\begin{array}{l}\text { Personel Memnuniyeti } \\
\text { (Faktör 3) }\end{array}$} & $1001-2500 \mathrm{TL}$ & 100 & 243,94 & \multirow{3}{*}{7,465} & \multirow{3}{*}{0,024} \\
\hline & 2501-4000TL & 171 & 221,06 & & \\
\hline & 4001 TL ve Üzeri & 167 & 203,26 & & \\
\hline \multirow{3}{*}{$\begin{array}{l}\text { Çalışanların Tutumu } \\
\text { (Faktör 4) }\end{array}$} & $1001-2500 \mathrm{TL}$ & 100 & 250,02 & \multirow[t]{3}{*}{11,693} & \multirow[t]{3}{*}{0,003} \\
\hline & $2501-4000 \mathrm{TL}$ & 171 & 222,37 & & \\
\hline & 4001 TL ve Üzeri & 167 & 198,28 & & \\
\hline \multirow{3}{*}{ Tesis Olanakları (Faktör 5) } & $1001-2500 \mathrm{TL}$ & 100 & 256,63 & \multirow{3}{*}{38,942} & \multirow{3}{*}{0,000} \\
\hline & $2501-4000 \mathrm{TL}$ & 171 & 242,83 & & \\
\hline & 4001 TL ve Üzeri & 167 & 173,38 & & \\
\hline \multirow{3}{*}{ Fiziksel Yap1 (Faktör 6) } & $1001-2500 \mathrm{TL}$ & 100 & 207,00 & \multirow{3}{*}{8,400} & \multirow{3}{*}{0,015} \\
\hline & 2501-4000TL & 171 & 239,87 & & \\
\hline & 4001 TL ve Üzeri & 167 & 206,12 & & \\
\hline \multirow{3}{*}{$\begin{array}{l}\text { İklimsel Memnuniyet (Faktör } \\
\text { 7) }\end{array}$} & 1001-2500TL & 100 & 205,38 & \multirow{3}{*}{8,150} & \multirow{3}{*}{0,017} \\
\hline & $2501-4000 \mathrm{TL}$ & 171 & 239,96 & & \\
\hline & 4001 TL ve Üzeri & 167 & 207,01 & & \\
\hline
\end{tabular}

Buna göre müşterilerin memnuniyet düzeyleri ile aylık ortalama gelirleri değişkenine göre; “Otel Memnuniyeti", "Termal Tesis Memnuniyeti", "Tesis Olanakları", "Personel Memnuniyeti", "Çalışanların Tutumu", "Fiziksel Yapı" ve "İklimsel Memnuniyet" faktörlerinde anlamlı bir farklılığın olduğu tespit edilmiştir $(\mathrm{p}<0,05)$. Müşterilerin aylık ortalama gelir değişkeninin, memnuniyet düzeyleri üzerinde etkili olduğunu söylemek mümkündür. 


\section{Termal Otel İşletmelerinde Konaklayan Müşterilerin Memnuniyet Düzeyleri ile Aynı Termal Oteli Tercih Edip Etmeme Arasındaki Farklılaşma Durumu}

Araştırmaya katılan termal otel işletmelerinde konaklayan müşterilerin memnuniyet düzeyleriyle daha önce buradaki termal otelde konaklama yapıp yapmama arasında, \%5 anlamlılık düzeyinde bir farklılık olup olmadığını anlamak amacıyla Mann-Whitney U Testi uygulanmış ve elde edilen bulgular Tablo 9'da verilmiştir.

Tablo 9. Termal Otel İşletmelerinde Konaklayan Müşterilerin Memnuniyet Düzeyleri ile Aynı Termal Oteli Tercih Edip Etmeme Arasındaki Farklılaşma Durumu

\begin{tabular}{|c|c|c|c|c|c|c|}
\hline $\begin{array}{l}\text { Müşteri } \\
\text { Memnuniyet } \\
\text { Boyutları }\end{array}$ & $\begin{array}{l}\text { Daha Önce Otelde } \\
\text { Konakladınız mı? }\end{array}$ & $\mathbf{N}$ & Sira Ortalaması & M.W.U. & Z & $\mathrm{p}$ \\
\hline \multirow{2}{*}{ Otel Memnuniyeti } & Evet & 233 & 232,09 & \multirow{2}{*}{20948,500} & \multirow{2}{*}{2,396} & \multirow{2}{*}{0,017} \\
\hline & Hayır & 205 & 205,19 & & & \\
\hline \multirow{2}{*}{$\begin{array}{l}\text { Termal Tesis } \\
\text { Memnuniyeti }\end{array}$} & Evet & 233 & 243,41 & \multirow{2}{*}{18311,500} & \multirow{2}{*}{$-4,335$} & \multirow{2}{*}{0,000} \\
\hline & Hayır & 205 & 192,32 & & & \\
\hline \multirow{2}{*}{$\begin{array}{l}\text { Personel } \\
\text { Memnuniyeti }\end{array}$} & Evet & 233 & 243,60 & \multirow{2}{*}{18267,000} & \multirow{2}{*}{$-4,552$} & \multirow{2}{*}{0,000} \\
\hline & Hayır & 205 & 192,11 & & & \\
\hline \multirow{2}{*}{$\begin{array}{l}\text { Çalışanların } \\
\text { Tutumu }\end{array}$} & Evet & 233 & 239,38 & \multirow{2}{*}{19250,500} & \multirow{2}{*}{$-3,682$} & \multirow{2}{*}{0,000} \\
\hline & Hayır & 205 & 196,90 & & & \\
\hline \multirow{2}{*}{ Tesis Olanakları } & Evet & 233 & 232,53 & \multirow{2}{*}{20846,500} & \multirow{2}{*}{$-2,370$} & \multirow{2}{*}{0,018} \\
\hline & Hayır & 205 & 204,69 & & & \\
\hline \multirow{2}{*}{ Fiziksel Yapı } & Evet & 233 & 228,81 & \multirow{2}{*}{21714,000} & \multirow{2}{*}{$-1,763$} & \multirow{2}{*}{0,078} \\
\hline & Hayır & 205 & 208,92 & & & \\
\hline \multirow{2}{*}{$\begin{array}{l}\text { İklimsel } \\
\text { Memnuniyet }\end{array}$} & Evet & 233 & 223,44 & \multirow{2}{*}{22963,500} & \multirow{2}{*}{$-0,733$} & \multirow{2}{*}{0,464} \\
\hline & Hayır & 205 & 215,02 & & & \\
\hline
\end{tabular}

Tablo 9'a göre termal tesislerde kalan müşterilerin memnuniyet düzeyleriyle daha önce buradaki termal otellerde konaklama yapıp yapmama arasında; "Otel Memnuniyeti", "Termal Tesis Memnuniyeti", "Tesis Olanakları", "Personel Memnuniyeti" ve "Çalışanların Tutumu", faktörlerinde anlamlı bir farklılığın olduğu $(\mathrm{p}<0,05)$; "Fiziksel Yapı" ve "İklimsel Memnuniyet" faktörlerinde anlamlı bir farklılığın olmadığı tespit edilmiştir ( $p>0,05)$. Döngel'de bulunan termal otel işletmelerinde konaklayan müşterilerin memnuniyetlerinin yüksek olduğu bulgusuna ulaşılmıştır.

Buna göre araştırmanın "Müşterilerin memnuniyet düzeyleri ile bazı demografik ve tanıtıcı özellikleri arasında anlamlı bir farklılık vardır." H2 hipotezi kabul edilmiştir.

\section{TARTIŞMA, SONUÇ ve ÖNERILLER}

Termal turizmin sağlık turizmi ile önem kazanmaya başladığı düşünülse de ilk uygarlıklardan beri varlı̆̆ını sürdürmektedir ancak dönemin ihtiyaçlarına göre kendini gösterdiği için fark edilememektedir. Geçmişte savaşlar sırasında yaralı askerlerin tedavi edilmesinde ihtiyaç duyulan termal turizm, son yılların en büyük sorunları olan stres, kalabalık, gürültü ve çevre kirliliğinden kaçmak isteyenlerin sağlık bulma çabası termal turizm sektörünü harekete geçirmiş ve yeniden fark edilmesini sağlamıştır (Dereli, 2019: 87). Türkiye' de sağlık turizminin ana ekseni termal turizm olsa da dünyada termal turizm, Spa (Kaplıca) olarak adlandırılan daha geniş bir 
turizm türünün bir parçası olarak kabul edilmekte ve ülkemizde de termal turizm haricindeki diğer Spa aktiviteleri de hızla gelişim göstermektedir. Son yıllarda özellikle Avrupa'da, 50 yaş altı kadın ve erkeklerin mevcut sağlığının sürekliliği için kaplıca ve sağlık faaliyetlerine ilginin artmasına ve gelişmesine neden olan Spa adı altında bir pazar gündeme getirilmiştir (Çelik, 2009: 14).

Kaplıcaların işletme sorunları, tanıtım, pazarlama ve donanım eksiklikleri potansiyelini tam kullanamamasına neden olmaktadır. Kahramanmaraş İli Onikişubat İlçesi Döngele kaplıcaları termal kaynaklarının özellikleri, iklimi ve konumuyla gelişmeye müsait bir durumdadır (Karademir vd., 2019: 647). Termal turizm işletmelerinde müşteri memnuniyeti, bireylerin aldıkları hizmet ya da ürünü kendi beklentileri doğrultusunda karşılaştırarak değerlendirmesidir. $\mathrm{Bu}$ değerlendirme sonucunda belirli bir memnuniyet düzeyi ortaya çıkmaktadır. Alınan hizmetler beklentileri karşıladığında memnuniyet düzeyi artarken, beklentileri karşılamadığı durumda ise memnuniyet düzeyi azalmaktadır (Yıldız, 2020: 97).

Araştırmanın sonuçlarına göre müşteri memnuniyet ölçeği yedi faktör altında toplanmıştır. Bunlar; otel memnuniyeti, termal tesis memnuniyeti, personel memnuniyeti, çalışanların tutumu, tesis olanakları, fiziksel yapı ve iklimsel memnuniyet şeklinde sıralanmıştır. Yedi faktör içerisinde yer alan sorulara ilişkin memnuniyet düzeyleri ve standart sapma değerleri $\bar{x}=4,01 \pm 1,05$ 'tir. Yapılan bu çalışma ile Kahramanmaraş'taki termal turizminden hizmet alan müşterilerin memnuniyet düzeylerinin yüksek olduğu söylenebilir. Müşteri memnuniyetlerini arttıran önemli hizmetler ise; konaklama işletmelerinin modern yapısı, odaların dizayn şekli, temizlik ve hijyen, otel çalışanlarında ki iletişim gibi maddeler yer almaktadır.

Yapılan analizlerde; müşteri memnuniyeti ile yaş faktörü arasında anlamlı farklılık bulunamamıştır. Turizm faaliyetlerine katılan genç yaş grubunda ki müşterilerin orta yaş grubunda ki müşterilerden memnuniyet dereceleri bakımından farklılık gösterdiği literatür tarafından desteklenmektedir. Yapılan bu çalışmada ise termal turizm faaliyetine katılan genç, orta ve üçüncü yaş grubundaki müşterilerin memnuniyet düzeyleri arasında anlamlı fark tespit edilememiştir $(\mathrm{p}>0,05)$.

Araştırmanın çarpıcı bir diğer sonucu ise; Termal otel işletmelerinde konaklayan müşterilerin eğitim durumları ile "otel memnuniyeti" $(p=0,026)$, "personel memnuniyeti" $(p=0,022)$, "tesis olanakları" ( $p=0,003)$ ve "iklimsel memnuniyet" $(p=0,001)$ faktörleri arasında anlamlı farklılık tespit edilmiştir $(\mathrm{p}<0,05)$. Otel memnuniyeti faktöründe lise $(\bar{x}=231,57)$, personel memnuniyeti faktöründe ilkokul $(\bar{x}=241,25)$, tesis olanaklarında lise $(\bar{x}=234,00)$ ve iklimsel memnuniyet faktöründe ise lise $(\bar{x}=252,41)$ mezunlarının memnuniyet değerlerinin daha yüksek olduğu görülmektedir. Bu sonuç 'un Keskin (2008)'in yaptı çalışma ile örtüştüğü görülmektedir.

Döngele Kaplıcalarında faaliyette bulunan turizm işletme belgeli “Orkis Palace Termal Otel "ve "Tatlısu Termal Otel'in konaklama olanakları, müşteri memnuniyetini yükselttiği sonucuna varılmıştır. Buna göre Aymankuy, Akgül ve Akgül (2012), Borodulin (2013) ve Karabacak (2019) tarafından yapılan araştırmaların sonuçlarıyla bu araştırmanın sonuçlarının benzer nitelikler taşıdığı tespit edilmiştir. Bulgulara göre termal turizmde müşteri memnuniyeti ile bazı demografik ve tanıtıcı özellikleri arasında farklılıkların olduğu tespit edilmiştir. Araştırmada demografik değişkenlere dayalı cinsiyet ve yaş değişkeninin müşteri memnuniyetini etkilemediği, eğitim değişkeni, aylık ortalama gelir ve müşterilerin aynı oteli tekrar tercih etmesi değişkeninin ise müşteri memnuniyetini etkilediği bulgusuna ulaşılmıştır. 


\section{ÖNERİLER}

Termal turizmi başka turizm çeşitleriyle sunmak, termal turizmin geliştirilmesi açısından önem arz etmektedir. Bu doğrultuda Döngele Bölgesinde, alternatif turizm türlerinin yapılması için çalışmaların başlatılması bölgenin turizm hareketliliği için ivme konumundadır. Çünkü bu bölge Sır Barajı eteklerinde yer almakla birlikte Baş konuş Milli Parkına da çok kısa mesafededir. Termal otel içerisinde ya da çevresinde yürüyüş parkurlarının yapılması müşteri memnuniyetinin arttırılmasında destekleyici bir unsurdur. Aynı zamanda bu bölgenin yeşilin ve mavinin buluştuğu noktada olmasından dolayı burada çeşitli su sporları düzenlenerek, spor turizmiyle bölgenin tanıtımının yapılmasına olanak tanınabilir. İlin tanıtımı yapılırken, dondurması, tarhanası, kayak merkezinin yanı sıra Kahramanmaraş İl genelinde bulunan doğal kaynakların da tanıtımlara dahil edilmesi çekiciliği artırabilir. Kahramanmaraş'a termal turizmin çekicilik unsuru olarak eklenmesi ve termal şifanın da önemine dikkat çekilmesi hem yerel turizmin hem de uluslararası pazarlara açılım noktasında, kazanım sağlayacağı söylenebilir.

\section{KAYNAKÇA}

Acayıp, E. (2012). Termal turizm işletmelerinde iç ve dış müşteri tatmini ilişkisi: Çeşme bölgesi işletmelerinde uygulama, Yüksek Lisans Tezi, Adnan Menderes Üniversitesi Sosyal Bilimler Enstitüsü, Aydın.

Amengual, A. H., Victor, R., Romu, A., Climent, S., and Climent, R. (2012). Projections of the Climate Potential for Tourism at Local Scales: Application to Platja de Palma, Spain. International Journal of Climatology, 32(14), 2095-2107.

Arslan, H. (2018). Alternatif Turizmin Bölge Ekonomisi Üzerindeki Etkisi: Samsun Örneği, Yüksek Lisans Tezi, Muğla Sıtkı Koçman Üniversitesi Sosyal Bilimler Enstitüsü, Muğla.

Aşık Akşit, N. (2014). Çalışanların iş doyumunu etkileyen bireysel ve örgütsel faktörler ile sonuçlarına ilişkin kavramsal bir değerlendirme. Türk İdare Dergisi, 467, 31-51.

Aşık Akşit, N. (2014). Termal Otel Müşterilerinin Memnuniyet Düzeylerini Belirlemeye Yönelik Bir Araştırma, Uluslararası Hakemli Pazarlama ve Pazar Araştırmaları Dergisi, 1(2), 109-123.

Aymankuy, Y., Akgül, V., ve Can Akgül, C. (2012). Termal Konaklama İşletmelerinde Müşteri Memnuniyetine Etki Eden Unsurlar "Gönen Kaplıcaları Örneği". Balıkesir Üniversitesi Sosyal Bilimler Enstitüsü Dergisi, 15(28), 223-240.

Balcığulları, A. (2013). Evliya Çelebi'nin Seyahatnamesinde Anadolu Şifalı Suları ve Günümüzün Termal Suları, Türkiye Sosyal Araştırmalar Dergisi, 173(173), 287-306.

Belber, B. G., Turan, A. (2015) Termal Turizm İşletmelerinde, Turistik Tüketicilerin Tatmin Düzeylerine Etki Eden Faktörlerin Belirlenmesi: Kırşehir İli Üzerine Bir Uygulama, İşletme Araştırmaları Dergisi, 7(3), 457-481.

Boekstein, M. (2014). From illness to wellness-has thermal spring health tourism reached a new turning point? African Journal of Hospitality, Tourism and Leisure, 3 (2), 1-11.

Boekstein, M. (2014). Tourism, health and the changing role of thermal springs - should South Africa reposition its thermal spring tourism product? African Journal of Hospitality, Tourism and Leisure, 3 (2): 1-9 
Boekstein, M.S., and Spenser, J. S. (2013). International trends in health tourism: Implications for thermal spring tourism in the Western Cape Province of South Africa. African Journal for Physical, Health Education, Recreation and Dance, 19(2), 287-298.

Boekstein, M.S., and Spencer, J. S. (2013). Activity-Based Market Segmentation of Visitors to Thermal Spring Resorts in the Western Cape Province, South Africa: Assessing the Potential for Health Tourism Development, African Journal for Physical, Health Education, Recreation and Dance, 19(4:2), 1100-1110.

Borodulin, H. (2013). Customer Satisfaction: Rantasipi Ikaalinen Spa, Yüksek Lisans Tezi, Tampere Uygulamalı Bilimler Üniversitesi, Finlandiya.

Boyraz, M. Çetin, A. (2018). Termal Otel İşletmelerinde Jeotermal Kaynak Kullanımının Yönetici Bakış Açısıyla Değerlendirilmesi: Denizli İli Örneği, Süleyman Demirel Üniversitesi Vizyoner Dergisi, 10(23), 84-98.

Bucak, T., ve Özkaya, E. (2013). Çanakkale İlinin Termal Turizm Potansiyeli. Aksaray Üniversitesi İktisadi ve İdari Bilimler Fakültesi Dergisi, 5(2), 7-23.

Büyüköztürk, Ş (2012). Sosyal Bilimler İçin Veri Analizi El Kitabı. Pegem Yayıncllı: Ankara.

Cadotte, E, R., Woodruff, R. B., and Jenkins, R. L. (1987). Expectation and norms in models of customer satisfaction. Journal of Marketing Research, (24), 305-314.

Çelik, A. (2009). Sağlık Turizmi Kapsamında Termal İşletmelerde Sağlık Hizmetleri Pazarlaması ve Algılanan Hizmet Kalitesi: Balçova Termal İşletmesinde Bir Uygulama, Yüksek Lisans Tezi, Dokuz Eylül Üniversitesi Sosyal Bilimler Enstitüsü, İzmir.

Çelik, S. (2009). Afyonkarahisar'da Uluslararası Termal Turizm Destinasyonu Oluşturma Potansiyelinin Analizi, Doktora Tezi, Afyon Kocatepe Üniversitesi Sosyal Bilimler Enstitüsü, Afyonkarahisar.

Çiçek, R., ve Avderen, S. (2013). Sağlık Turizmi Açısından İç Anadolu Bölgesi'ndeki Kaplıca ve Termal Tesislerin Mevcut Yapısının ve Potansiyelinin Belirlenmesine Yönelik Bir Araştırma, Karamanoğlu Mehmet Bey Üniversitesi Sosyal ve Ekonomik Araştırmalar Dergisi, 15(25), 25-35.

Çontu, M. (2006). Alternatif Turizm Çeşitleri ve Kızılcahamam Termal Turizm Örneği, Yüksek Lisans Tezi, Abant İzzet Baysal Üniversitesi Sosyal Bilimler Enstitüsü, Bolu.

Eleren, A., ve Kiliç, B. (2007). Turizm Sektöründe SERVQUAL Analizi ile Hizmet Kalitesinin Ölçülmesi ve Bir Termal Otelde Uygulama, Afyon Kocatepe Üniversitesi İktisadi ve İdari Bilimler Fakültesi Dergisi, 9(1), 235-263.

Emir, O. ve Saraçli, S. (2011). Determinants of Customer Satisfaction with Thermal Hotels. Anatolia, 22(1), 56-68.

Erdoğan, E., ve Aklanoğlu, F. (2008). Termal Turizm ve Afyon Gazlıgöl Örneği, EJournal of New World Science Academy, 3(1), 83-92.

Göçmen Güvercin, Z. (2008). Turizm Çeşitlendirmesi Kapsamında İzmir'de Termal Turizmin Tedavi Amaçlı Kullanımı ve Ekonomik Değeri, Yüksek Lisans Tezi, Dokuz Eylül Üniversitesi Sosyal Bilimler Enstitüsü, İzmir.

http://www.kahramanmaras.gov.tr/ekinozu, Erişim Tarihi: 11.10.2019

https://www.kulturportali.gov.tr/turkiye/kahramanmaras/turizmaktiviteleri/goksunbuyukkizilcik-cmesi, Erişim Tarihi: 07.10.2019 
https://yigm.ktb.gov.tr/TR-11481/termal-turizm-master-plani-2007-2023.html, Erişim Tarihi: 28.01.2021

https://kahramanmaras.ktb.gov.tr/TR-61248/termal-turizm.html, Erişim Tarihi: 12.10.2019

https://www.kulturportali.gov.tr/turkiye/denizli/gezilecekyer/karahayit, Erişim Tarihi: 01.02.2020

Kalaycı, Ş. (2009). SPSS Uygulamalı Çok Değiş̧kenli İstatistik Teknikler, 4. Baskı, Asil Yayın Dağıtım: Ankara.

Karabacak, M. (2019). Termal Turizm İşletmelerinde Hizmet Kalitesi Ölçümü Üzerine Bir Araştırma, Yüksek Lisans Tezi, Tokat Gaziosmanpaşa Üniversitesi İktisadi ve İdari Bilimler Fakültesi, Tokat.

Karademir, N., Sandal Kaya, E. ve Bilinir, Ş. (2019). Döngele Kaplıcası (Kahramanmaraş)'nın Termal Turizm Potansiyeli ve Sosyo-Ekonomik Katkıları, Kahramanmaraş Sütçü İmam Üniversitesi Sosyal Bilimler Dergisi, 16(2), 640-670.

Kervankıran, İ. (2013). Afyonkarahisar İlinin Sürdürülebilir Turizm Açısından Değerlendirilmesi, Kocatepe Akademi Yayınları: Afyonkarahisar.

Keskin, Y. (2008). Termal Turizm İşletmelerinde Müşteri Tatmininin Ölçülmesi Kızılcahamam Örneği, Yüksek Lisans Tezi, Düzce Üniversitesi Sosyal Bilimler Enstitüsü, Düzce.

Kılıç, Ö. (2018). Lisans Düzeyinde Turizm Eğitimi Alan Öğrencilerin Uygulama Oteli Algıları: Eskişehir Osmangazi Üniversitesi Örneği, Yüksek Lisans Tezi, Eskişehir Osmangazi Üniversitesi Sosyal Bilimler Enstitüsü, Eskişehir.

Kireçci, E., Uğuz Tansu, M., ve Aral, M. (2017). Kahramanmaraş İlindeki İçme, Kullanma ve Çevresel Suların Mikrobiyolojik Niteliğinin Membran Filtrasyon Sistemi ile Belirlenmesi. KSÜ Doğa Bilimleri Dergisi, 20(1), 20-24

Koskinen, V., and Wilska, T. A. (2019). Identifying and Understanding Spa Tourists' Wellness Attitudes, Scandinavian Journal of Hospitality and Tourism, 19(3), 259-277.

Leandro, M. E., Nogueira, F., and Carvalho, A. B. S. (2015). Diversity and Interconnection: Spas, health and Wellness Tourism, In Health and Wellness Tourism, 1-5.

Olcay, A. ve Giritlioğlu, İ. (2014). Gaziantep Bölgesinde Şehir Turizmine Hizmet Veren Otellerde Müşteri Memnuniyeti Üzerine Bir Araştırma, Elektronik Sosyal Bilimler Dergisi, 13(50), 1-22.

Olcay, A., ve Sürme, M. (2014). Otel İşletmelerinde Müşteri Şikâyetlerini Belirlemeye Yönelik Ampirik Bir Çalışma, Uluslararası Sosyal Araştırmalar Dergisi, 7(35), 836-855.

Özbek, D. ve Özbek, T. (2008). Jeotermal Kaynakların Sağlık ve Termal Turizme Entegrasyonu, Jeotermal Haber Bülteni, (2-3), 99-113.

Özşahin, E., ve Kaymaz, Ç. K. (2013). Türkiye'nin Termal Su Kaynaklarının Coğrafi Açıdan Değerlendirilmesi, Atatürk Üniversitesi Sosyal Bilimler Dergisi, (50), 25-37.

Öztürk, Y., ve Kenzhebayeva, A. (2013). Turizm Sektöründe Hizmet Kalitesi: Türkiye ve Kazakistan'daki Termal Otel İşletmelerinde Karşılaştırılmalı Bir Araştırma. Journal of Tourism and Gastronomy Studies, 1(4), 35-46.

Sandıkçı, M. (2008). Termal Turizm İşletmelerinde Sağlık Beklentileri ve Müşteri Memnuniyeti, Doktora Tezi, Afyon Kocatepe Üniversitesi Sosyal Bilimler Enstitüsü, Afyonkarahisar. 
Sav, D. (2016). Müşteri Beklentileri ve Memnuniyetinin Stratejik Planlama Açısından Değerlendirilmesi: Afyonkarahisar İlindeki Termal Turizm İşletmeleri Üzerinde Bir Araştırma, Doktora Tezi, İstanbul Üniversitesi Sosyal Bilimler Enstitüsü, İstanbul.

Silvestri, C., Aquilani, B. and Ruggieri, A. (2017). Service quality and customer satisfaction in thermal tourism, The TQM Journal, 29(1), $55-81$

Şahin, A., Şen, S. (2017). Hizmet Kalitesinin Müşteri Memnuniyeti Üzerine Etkisi, Journal of International Social Research, 10(52), 1176-1184.

Şengül, H. ve Bulut, A. (2019). Sağlık turizmi çerçevesinde Türkiye'de termal turizm; bir SWOT analizi çalışması, ESTÜDAM Halk Sağhı̆̆ı Dergisi, 4(1), 55-70.

Tam, J. L. M. (2011). The moderating effects of purchase importance in customer satisfaction process: An empirical investigation. Journal of Consumer Behaviour, 10(4), 205-215.

Uçar, M (2017). Gaziantep Tarihi Su Sisteminin Osmanlı Dönemindeki Yönetimi. Yıldız Teknik Üniversitesi mimarlık Fakültesi E-Dergisi, 12(1), 157-169.

Uslu, Ö. S. ve Kaya, A. R. (2015). Kırsal Turizm Alanında Tarım ve Kırsal Kalkınmayı Destekleme Kurumu (TKDK) Destekleri: Kahramanmaraş Örneği, Uluslararası Sosyal ve Ekonomik Bilimler Dergisi, 5(2), 17-24.

Usta, N. ve Zaman, M. (2015). Kızılcahamam İlçesi Turizminde Termal Kaynakların Önemi, Atatürk Üniversitesi Sosyal Bilimler Enstitüsü Dergisi, 19(2), 187-208.

Yıldız, Y. (2020). Termal Turizmde Müşteri Memnuniyeti ve Yaşam Kalitesi Algısı: Ankara Kızılcahamam Örneği, Yüksek Lisans Tezi, Balıkesir Üniversitesi Sosyal Bilimler Enstitüsü, Balıkesir.

Zhao, Q. (2017). A Study of Factors Influencing Chinese Spa Service Tourists to Revisit Bangkok, Master Thesis, International College University of the Thai Chamber of Commerce, Thailand. 